$G \quad E \cup S$

Report file no.

22251

GRØNLANDS GEOLOGISKE UNDERSØGELSE

BULletin No. 99

\title{
CORYPHOID PALM FRUITS AND SEEDS FROM THE DANIAN OF NÛGSSUAQ, WEST GREENLAND
}

BY

B. ESKE KOCH

WITH 1 TABLE AND 10 FIGURES IN THE TEXT, AND 18 PLATES

KØBENHAVN

1972 


\section{GRøNLANDS GEOLOGISKE UNDERSØGELSE The Geological Survey of Greenland

\author{
Østervoldgade 10, DK-1350 København K
}

Denmark

\section{BULLETINS}

(published in association with the series Meddelelser om Gronland)

No. 89 The significance of the kakortokite in the evolution of the Ilimaussaq intrusion, South Greenland. 1970 by John Ferguson (Meddr Gronland $190,1)$.

No. 90 The chemistry and origin of some basement amphibolites between Ivigtut and Frederikshåb, South-West Greenland. 1970 by Feiko Kalsbeek and Bernard E. Leake (Meddr Gronland 190,4).

No. 91 Plutonic nodules in lamprophyric carbonatite dykes near Frederikshåb, South-West Greenland. 1970 by Brian J. Walton and Allan R. Arnold (Meddr Gronland 190,5).

No. 92 The geology of two small layered hornblende peridotite (picrite) plutons in South Greenland. 1970 by Jevan P. Berrangé (Meddr Gronland 192,1).

No. 93 Danian foraminifera from Nûgssuaq, West Greenland. 1970 by Hans Jørgen Hansen (Meddr Gronland 193, 2).

No. 94 Paleocene Ostracoda from Nûgssuaq, West Greenland. 1971 by Janina Szczechura (Meddr Gronland 193, 1).

No. 95 Contributions to the mineralogy of Ilimaussaq nos 20-21. I. On the mineralogy and paragenesis of tugtupite $\mathrm{Na}_{8} \mathrm{Al}_{2} \mathrm{Be}_{2} \mathrm{Si}_{8} \mathrm{O}_{24}(\mathrm{Cl}, \mathrm{S})_{2}$ from the Ilimaussaq alkaline intrusion, South Greenland. 1971 by H. Sørensen, M. Danø and O.V. Petersen (Meddr Gronland 181,13). II. The colour and luminescence of tugtupite (beryllosodalite) from Ilimaussaq, South Greenland. 1971 by A. S. Povarennykh, A. N. Platonov, A. N. Tarashchan and V.P. Belichenko (Meddr Gronland 181, 14).

No. 96 The Precambrian, Eocambrian and early Palaeozoic stratigraphy of the Jørgen Brønlund Fjord area, Peary Land, North Greenland. 1971 by Hans F. Jepsen (Meddr Gronland 192, 2).

No. 97. Kaledonische Metamorphose der praekambrischen Charcot Land Serie, Scoresby Sund, Ost-Grönland. 1971 by Albrecht Steck (Meddr Gronland 192,3$)$.

No. 98. Fossil Picrodendroid fruit from the Upper Danian of Nûgssuaq, West Greenland. 1972 by B. Eske Koch (Meddr Gronland 193,3).

No. 99. Coryphoid palm fruits and seeds from the Danian of Nûgssuaq, West Greenland. 1972 by B. Eske Koch (Meddr Gronland 193, 4).

Bulletins of the Geological Survey of Greenland are asailable on exchange or may be purchased from the Survey. Copies may be purchased as parts of Meddelelser om Grønland from C. A. Reitzels Forlag, Norre Søgade 35, DK-1370 Copenhagen $K$, Denmark. 
GRØNLANDS GEOLOGISKE UNDERSØGELSE

Bulletin No. 99

\title{
CORYPHOID PALM FRUITS AND SEEDS
} FROM THE DANIAN OF NÛGSSUAQ, WEST GREENLAND

\author{
BY \\ B. ESKE KOCH
}

WITH 1 TABLE AND 10 FIGURES IN THE TEXT, AND 18 PLATES

KØBENHAVN

1972 


\begin{abstract}
Two species of coryphoid palm fruits are described, Coryphoides poulseni n.gen. et n.sp. and Coryphoicarpus globoides n.gen. et n.sp. The former has been found in the Upper Danian (formerly Lower Paleocene) of Qaersutjægerdal in central Nûgssuaq, the latter in the Lower Danian of the valley of Tunorssuaq, Nûgssuaq.

The chief criteria for the determination of these fossil species as coryphoid palms are: 1) the big bulbous ingrowth from the functional pericarp of the placental region into the seed along the axis of the fruit (here called the columella), 2) the seed consisting mainly of a large cup-shaped endosperm, surrounding the columella, and 3 ) the small, saccate embryo inserted from the surface of the seed into the endosperm.

Coryphoides poulseni n.gen. et n.sp. is distinguished by the position of the embryo, the existence of a 'chalaza valve' and the characteristics of the columella, including the shape of the placental scar.

Coryphoicarpus globiodes n.gen. et n.sp. shows the same basic structure as Coryphoides poulseni n.gen. et n.sp., but differs from the latter in size and shape of the placental scar, shape of columella, course of the funiculus, position of chalaza, shape of 'the chalaza valve' and the position of the embryo.

The determinations are based upon a comparative study of a number of recent coryphoid palms and of Palmospermum excavatum Reid \& Chander.
\end{abstract}




\section{CONTENTS}

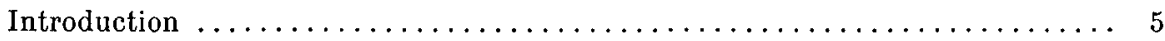

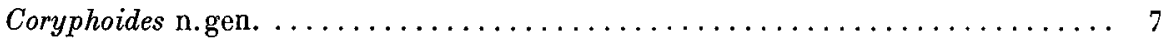

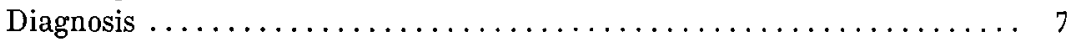

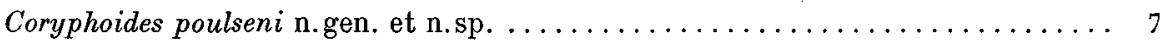

Diagnosis . . . . . . . . . . . . . . . . . . . . .

State of preservation $\ldots \ldots \ldots \ldots \ldots \ldots \ldots \ldots \ldots \ldots \ldots \ldots \ldots$

Orientation of the fossil structure $\ldots \ldots \ldots \ldots \ldots \ldots \ldots \ldots \ldots \ldots \ldots$

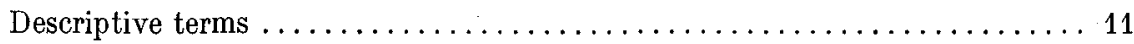

Morphology of the fossil fruit $\ldots \ldots \ldots \ldots \ldots \ldots \ldots \ldots \ldots \ldots \ldots \ldots \ldots$

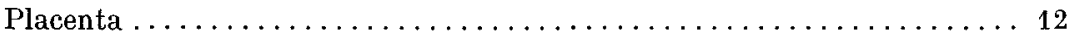

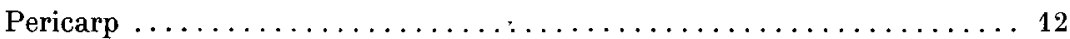

Columella ............................... 13

The cellular tissues of the columella $\ldots \ldots \ldots \ldots \ldots \ldots \ldots \ldots \ldots$

State of preservation of the columella structure $\ldots \ldots \ldots \ldots \ldots \ldots \ldots$

Morphology of the seed $\ldots \ldots \ldots \ldots \ldots \ldots \ldots \ldots \ldots \ldots \ldots \ldots \ldots \ldots \ldots$

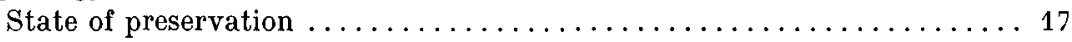

Nucellus ............................... 17

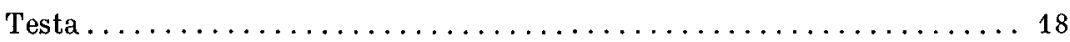

Raphe................................ 19

Chalaza valve $\ldots \ldots \ldots \ldots \ldots \ldots \ldots \ldots \ldots \ldots \ldots \ldots \ldots \ldots \ldots \ldots \ldots \ldots$

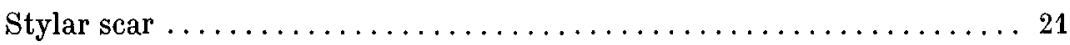

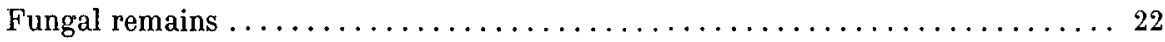

Interpretation of X-ray photographs $\ldots \ldots \ldots \ldots \ldots \ldots \ldots \ldots \ldots \ldots \ldots$

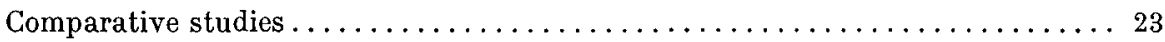

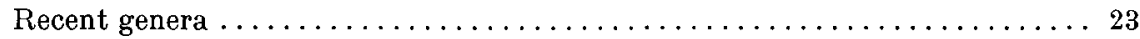

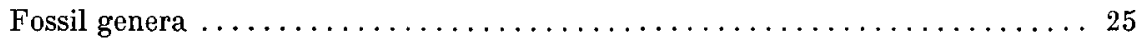

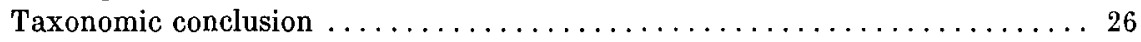

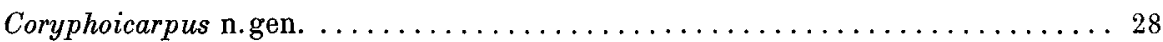

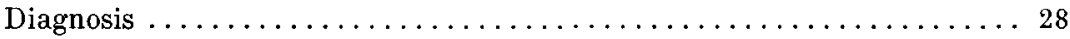

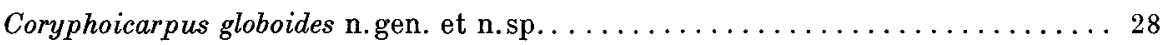

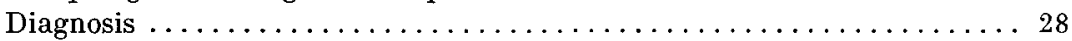

Description of the fossil $\ldots \ldots \ldots \ldots \ldots \ldots \ldots \ldots \ldots \ldots \ldots \ldots \ldots$

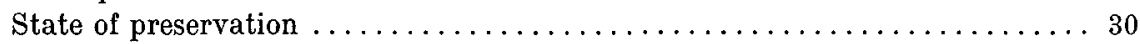

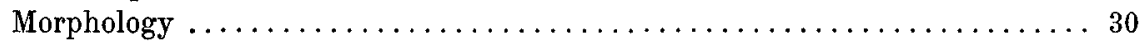

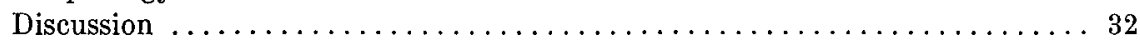

Taxonomic conclusion $\ldots \ldots \ldots \ldots \ldots \ldots \ldots \ldots \ldots \ldots \ldots \ldots \ldots \ldots \ldots \ldots$

Probably synchronous palm leaves $\ldots \ldots \ldots \ldots \ldots \ldots \ldots \ldots \ldots \ldots \ldots \ldots$

Acknowledgements . . . . . . . . . . . . . . . . . . . . . . . 35

Selected bibliography $\ldots \ldots \ldots \ldots \ldots \ldots \ldots \ldots \ldots \ldots \ldots \ldots \ldots \ldots \ldots$ 


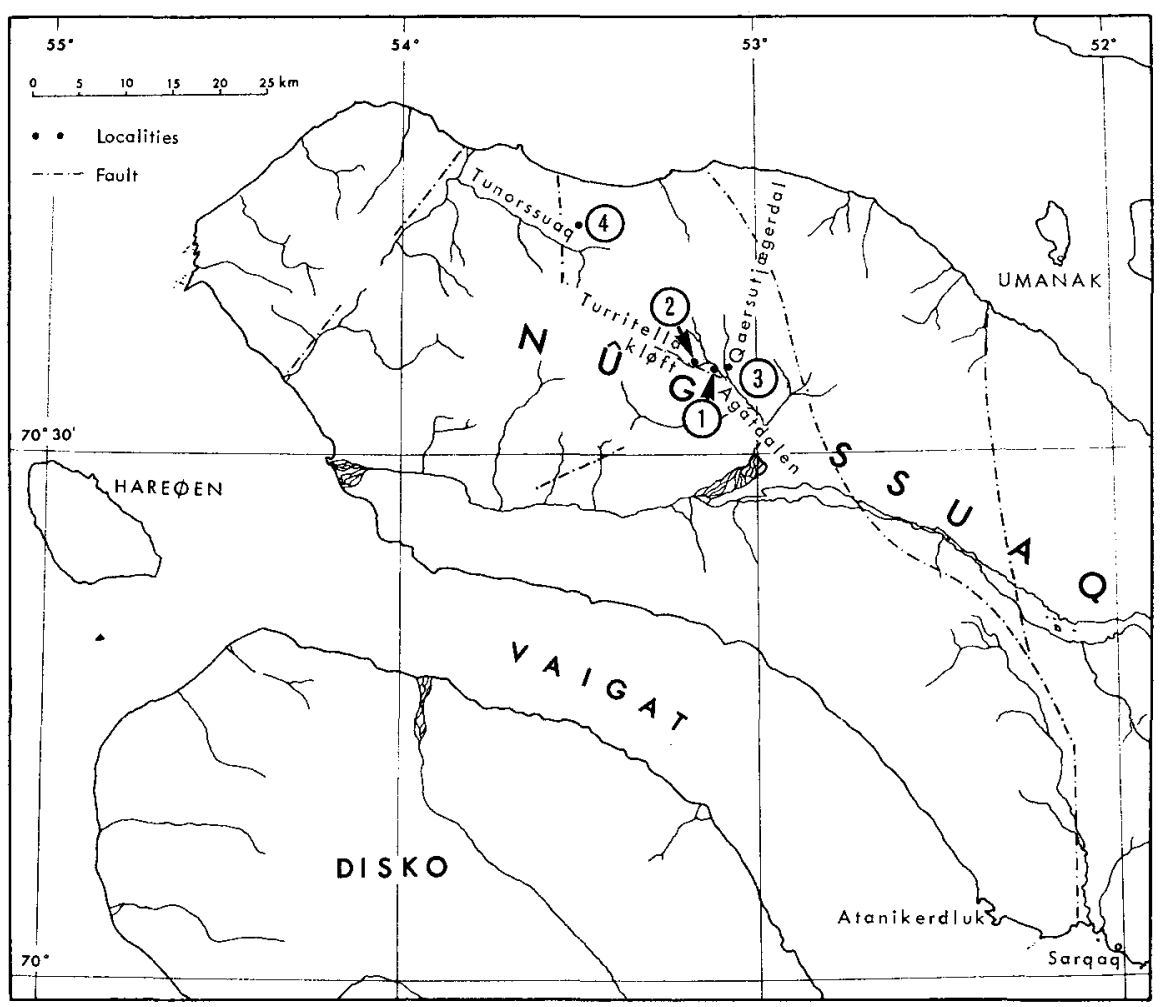

Fig. 1. Map of Nûgssuaq, West Greenland showing the Iocalities in question: 1: Agatkløft. 2: Scaphitesnæesen, and big section, Turritellakløft. 3: big section, Qaersutjægerdal. 4: Danienkløft, Tunorssuaq. 


\section{INTRODUCTION}

$\mathrm{T}$ his publication describes fossil fruits and seeds from localities in the interior of Nûgssuaq, West Greenland, where Danian deposits are exposed (textfig. 1).

The fossil material was collected by Professor A. Rosenkrantz and his colleagues during the expeditions to Nûgssuaq led by Professor A. Rosenkrantz, since 1946 under the auspices of the Geological Survey of Greenland. The author participated in some of these expeditions.

The specimens of Coryphoides poulseni were collected from the deltaic deposits of the Agatdal Formation consisting of deltaic and interdigitating marine beds in Agatdalen. Marine fossils are abundant and from a study of the molluses Professor A. Rosenkrantz assigned a Lower Paleocene age to them (Косн, 1963), since modified to Upper Danian (Rosenkrantz, 1970). Because of the geographical position, isolated from areas with synchronous deposits, stratigraphic correlation is difficult and it is complicated by the current discussion on the CretaceousTertiary boundary and the position of the Danian.

Coryphoicarpus globoides is so far the only determinable plant fossil from the marine, black shales of the Propeamussium Member of the Kangilia Formation in Tunorssuaq. A Lower Danian age is assigned to this formation by RosenkRANTz (1970) on the basis of marine molluscs. 


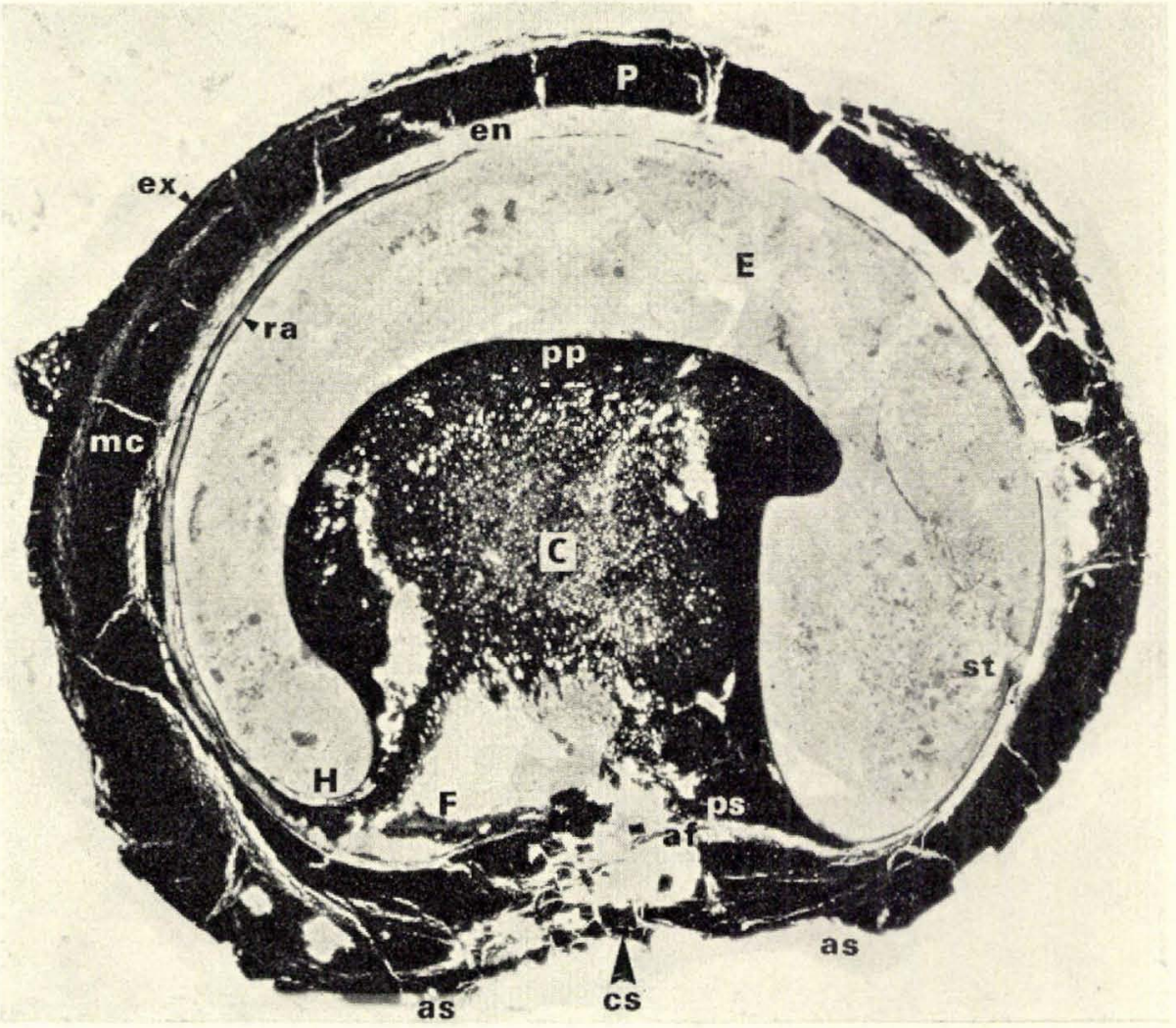

Fig. 2. Coryphoides poulseni n.gen. et n.sp. Length-section through a fruit along the plane of symmetry, through the raphe and the stylar scar. A number of terms used in the present paper is demonstrated by letters:

af: abscission fissure between pericarp and seed.

as: abscission scar of the fruit.

C: columella

cs: conducting strand of abscission scar (petiolar strand).

$\mathrm{E}$ : endosperm.

en: endocarp

ex: exocarp

$\mathrm{F}$ : funiculus
$\mathrm{H}$ : hilum

mc: mesocarp

P: pericarp

pp: peripheral palisade of the columella

ps: placental scar

ra: raphe

st: stylar scar (stylus). 


\title{
CORYPHOIDES
}

n. gen.

\section{Diagnosis}

Coryphoid palm fruits with the following characters:

Small, l-locular fruit with thick pericarp, containing 1 seed. The fruit is sub-globular, bilaterally symmetrical with a big abscission scar. Stylus basal, near the border of the placental scar in the plane of symmetry, opposite to the raphe of the seed. From the placental region a big bulbous columella penetrates into the seed; the seed is cup-shaped with its hollow corresponding to the shape of the columella. The columella has in the opposite position two blunt ridges in the plane of symmetry leaving corresponding sinuses in the hollow of the seed. The seed consists of a large endosperm with a small saccate embryo projecting from the surface of the seed at right angles into the endosperm. In an equatorial cross-section of the seed the embryo is situated about $135^{\circ}$ in clock-wise direction from the raphe end of the symmetry plane, when viewed from the proximal end of the seed axis.

The seed derives from a campylotropous ovule: raphe long, reaching from the placental scar to the distal pole of the seed.

\section{CORYPHOIDES POULSENI}

\author{
n. gen. et n. sp.
}

(textfigs 2-8; plates 1-13, and 17, fig. 2).

Holotypus: Specimen GGU no. 8179.2 (pl. 1, fig. 3A-B, pl. 17, fig. 2).

Locus typicus: Big section, Qaersutjægerdal, Nûgssuaq (Косн, 1959, fig. 35 , point 2).

Stratum typicum: The beds of the Agatdal Formation exposed in the big section, Qaersutjægerdal. Upper Danian (pp. 4-5).

\section{Diagnosis}

Small, coryphoid palm fruits and seeds with the following characters: The fruit has a thick pericarp and is l-locular, containing 1 seed. 
The fruit is sub-globular (reniform) with a big abscission scar; the conducting strand enters the centre of the abscission scar and proceeds through the placental scar of the seed. The proportion between diameter of the placental scar and diameter of the seed is well above 0.5.

Stylus placed basally on the fruit, outside the placental scar in the median plane (plane of symmetry). The pericarp has 3 layers with predominantly thick-walled cells. The fruit contains one seed, originating

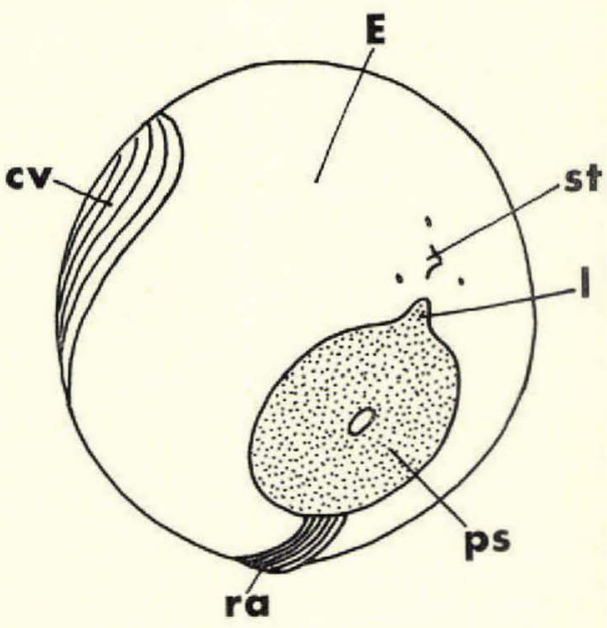

Fig. 3. Coryphoides poulseni n. gen. et n.sp. Generalized sketch showing the outstanding morphological features of the fossil seed of C.poulseni. ps: the placental scar (and base of the columella-structure). E: endosperm. 1: 'lip'. ra: raphe. cv: chalaza valve covered with conducting strands of the raphe structure. st: stylar scar. About $\times 4^{1 / 2}$.

from a campylotropous ovule. The testa is rudimentary and consists of one(?) cell layer. The seed contains a big, cup-shaped endosperm, surrounding a big bulbous ingrowth of the pericarp entering from the placental region (a simple rumination or placental columella). A small, saccate embryo is found laterally in the equatorial zone of the seed at the surface of the endosperm, projecting from the surface of the seed at right angles into the endosperm.

Coryphoides poulseni $\mathrm{n}$.gen. et $\mathrm{n}$. sp. is erected on fossils from the big outcrop on the western side of the canyon Agatkløft, at Scaphitesnæsen in Turritellakløft and the big section, Qaersutjægerdal (textfig. 1) (Rosenkrantz pers. comm. in Koch, 1963, Koch, 1967 and Rosenkrantz, 1970).

\section{State of preservation}

The fossils vary in state of preservation. Different combinations of incoaling, impregnation of the tissues by organic as well as inorganic 
secondary matter and replacement by inorganic matter occur. The pericarp is entirely preserved in some specimens (pl. 1, fig. $6 \mathrm{~A}-\mathrm{B}, \mathrm{pl} .2$ ) or partly in others (GGU no. 8179.2; 9249.65; 9249.67; 9249.70; 11711.7; 28955.41) (pl. 1, fig. 4; pl. 4, fig. 1-2) or has been lost (GGU no. 8173.4; $8177 ; 8179.3 ; 9249.64 ; 9249.66$ ) (pl. 1, figs 1, 2, 8), so that only the seed or even the nucellus with the columella is left without any coating or with only remnants of the pericarp. In this state the fossil is very characteristic (e.g. pl. 1, fig. 1A-B) and easily recognizable. Finally, impressions have been found with remnants of the incoaled pericarp (GGU no. 12896.248).

The pericarp has been found in an incoaled state (pl. 2) or is preserved in incoaled matter which has been consolidated by mineralization (calcification). In the consolidated state large sections of the pericarp can be removed. The nucellus is calcified, and the original tissue is totally replaced (pl. 2; pl. 3, figs 1, 2, 4A-B; pl. 4, figs 1-2) and only ghost cellular structures can be found in exceptional specimens (p. 17). In many cases recrystallization of the calcite has taken place resulting in a total destruction of the organic structures (pl. 4, fig. 2). In the placental ingrowth into the seed (the columella) there are pockets of incoaled tissue in combination with mineralized tissue. (pl. 2). A large volume is often totally replaced by calcite (pl. 3, fig. 4B; pl. 7, fig. 3 ; pl. 8, fig. 1) which may be recrystallized. Infilling of sediment in cavities left by early destruction of the tissue is often found (pl. 3, fig. 4A; pl. 7, fig. 3).

A reasonable interpretation of the fossil structure, and even the details of these fossil seeds, is often facilitated by taking into account the state of preservation and the processes which have changed the original structure into the fossil structure. For this reason the author in a few of the descriptive sections gives a special account of the state of preservation. The reader is also referred to the sections on fungal remains (p. 22), and columella (pp. 13-15).

\section{Orientation of the fossil structure}

When describing the fossil structure the author uses the following terms which for convenience are defined here (textfig. 4).

The axis: the line from the centre of the abscission scar of the fruit (i.e. the centre of the basal scar of the placental columella, on the seed) through the centre of the entire globular structure to its opposite pole.

The median plane: longitudinal plane containing the axis, the raphe and the basal scar of the stylus. Synonymous with plane of symmetry.

The equator: defined as normal to the mid-point of the axis.

The structure's equatorial plane is an ellipse, thus there is a short axis and a long axis: the equatorial s-axis and l-axis. 


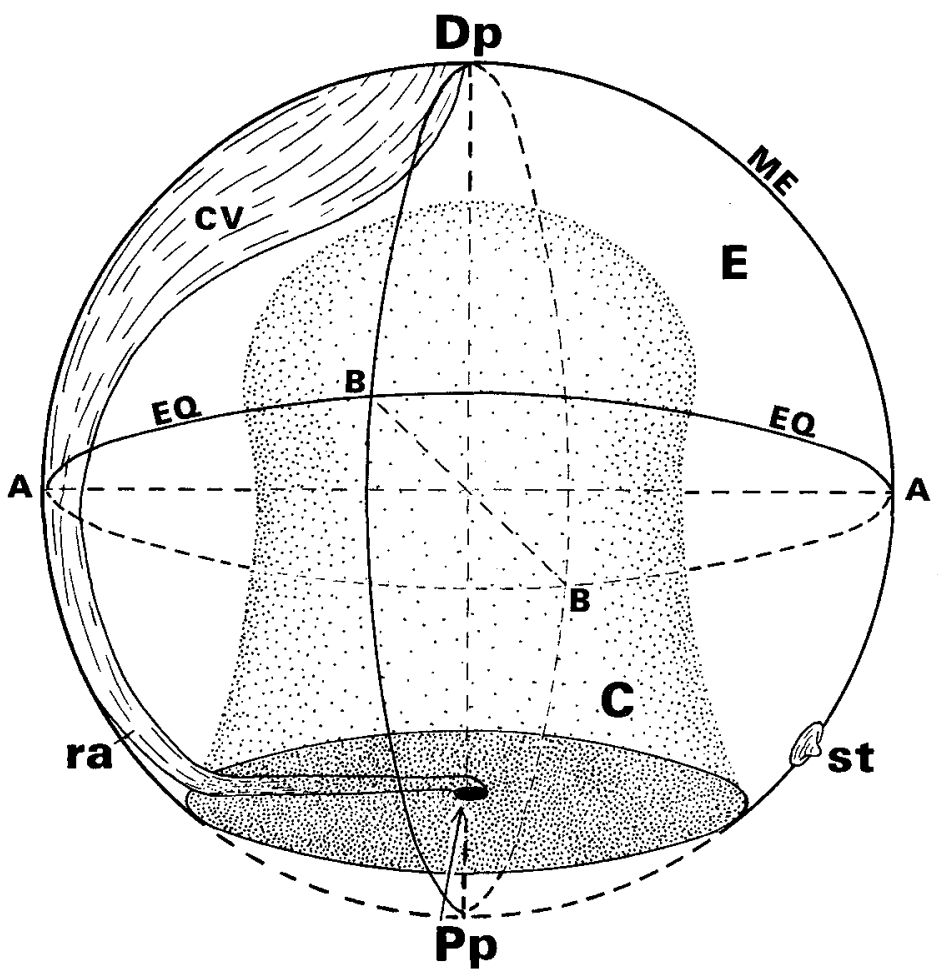

Fig. 4. Diagram demonstrating the nomenclature used here in the description of the fossil palm seeds. A-A: the long equatorial axis. B-B: the short equatorial axis. $\mathrm{EQ}$ : equator and equatorial plane. $\mathrm{ME}$ : median plane $=$ symmetry plane. $\mathrm{Pp}-\mathrm{Dp}$ : the axis. C: columella (coarse dotting). cv: chalaza valve. Dp: distal pole. E: endosperm. Pp: proximal pole. ra: raphe. st: stylar scar. Coarse dotting: columella. Fine dotting: placental scar.

\section{Descriptive terms}

The columella: an ingrowth of the functional pericarp from the placental region deep into the globular fruit in the direction of the axis (pl. 2, fig. $1 \mathrm{~A}$, textfigs 2, 4,6).

The chalaza valve: a circular valvate structure of the surface of the seed on the plane of symmetry; a structure in which the raphe terminates (pl. 17, fig. 2; textfigs 3, 4).

The placental scar: a big, round scar on the proximal end (the placental region) of the fossil seed which represents the basis of the columella (pl. 1, fig. 1 B, 2B; textfigs 3, 5). 


\section{Morphology of the fossil fruit}

Some of the fossils have undergone deformation, others have not. In general the original, undeformed fruits can be described as sub-globular (tending to reniform). The reniform tendency appears best in the median sections (pl. 2, fig. 1 A; pl. 3, fig. 4A).

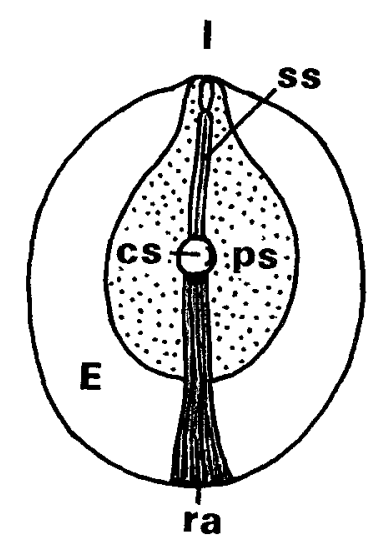

Fig. 5. Coryphoides poulseni n.gen. et n.sp. Generalized sketch showing the proximal end of the seed. ps (dotted): placental scar. E: endosperm. 1: 'lip' structure. cs: scar left by the entering petiolar strand. ra: raphe. ss: secondary strand. About $\times 4$.

The dimensions of the fossil fruits and seeds can be described by the length of the three axes. The long and intermediate axes are situated in the equatorial plane, the long axis in the plane of symmetry, the intermediate at right angles to the latter. The short axis is identical with the axis of the fruit and the seed at right angles to the equatorial plane.

\begin{tabular}{|c|c|c|c|}
\hline Fruits & $\begin{array}{c}\text { long axis } \\
(\mathrm{mm})\end{array}$ & $\begin{array}{c}\text { intermediate } \\
\text { axis } \\
(\mathrm{mm})\end{array}$ & $\begin{array}{c}\text { short axis } \\
\text { (mm) }\end{array}$ \\
\hline $\begin{array}{r}\text { GGU } 9249.62 \ldots \ldots \ldots \ldots \ldots \\
-\quad 9249.69 \ldots \ldots \ldots \ldots\end{array}$ & $\begin{array}{c}10.8 \\
(10.5)\end{array}$ & $(10.0)$ & 8.9 \\
\hline \multicolumn{4}{|l|}{ Seeds } \\
\hline GGU $8573.4 \ldots \ldots \ldots \ldots$ & 8.0 & & 6.1 \\
\hline - 8177 & 7.4 & 6.9 & 5.6 \\
\hline$-8179.2 \ldots \ldots \ldots \ldots \ldots$ & 8.9 & 8.5 & 8.0 \\
\hline$-\quad 8179.3 \ldots \ldots \ldots \ldots \ldots$ & 9.2 & 8.5 & 7.4 \\
\hline$-\quad 9249.62 \ldots \ldots \ldots \ldots \ldots$ & 8.5 & & 7.1 \\
\hline$-\quad 9249.64 \ldots \ldots \ldots \ldots \ldots$ & 7.8 & 7.3 & 6.7 \\
\hline$-9249.65 \ldots \ldots \ldots \ldots$ & 7.6 & & 6.3 \\
\hline - $9249.66 \ldots \ldots \ldots \ldots$ & 8.9 & & 7.6 \\
\hline$-\quad 9249.69 \ldots \ldots \ldots \ldots$ & 8.8 & 8.3 & \\
\hline$-9249.70 \ldots \ldots \ldots \ldots$ & 7.8 & 7.7 & $7.0 ?$ \\
\hline
\end{tabular}




\section{Placenta}

A fossil specimen with well-preserved pericarp (pl.1, fig. 6A-B) shows a large, basal abscission scar (covering the placental region) with another small central scar left by the entering conducting strand. The latter scar is a small groove from which an original calcite infilling has probably disappeared. The entrance of this calcified strand is seen on the pericarp of the fossil specimen (pl. 1, fig. 3B). Unless a small piece of the pericarp tissue has been removed from the proximal region (the placental region) the entering strand is seen in cross-section (pl. 1, fig. $3 \mathrm{~B})$. On the same specimen a branch leaves the main strand. From the cross section of the main strand a white (calcite) line runs radially to and passes over the periphery of the placental region in the median plane (pl. 1, fig. 3B). This line possibly indicates a pericarpal strand. It passes the border of the placental region opposite to the raphe. Hence, the primary conducting strand which enters the fruit at the abscission scar may have pericarpal strands issuing from it, of which one can be directly seen to branch off on the type specimen (pl. 1, fig. 3B).

When the entering conducting strand has passed through the functional pericarp of this region, it turns into a radial direction in the plane of symmetry and runs to the periphery of the placental scar of the seed. This part of the strand is interpreted as the funiculus. Hence, the basal region below the abscission scar represents the placenta.

\section{Pericarp}

The entire pericarp is preserved on GGU no. 9249.62 and GGU no. 9249.69 (pl. 2 ; pl. 3, figs 1-2), but the incoaling has led to a high degree of impregnation of the tissue by colloidal coal material. This precludes a detailed anatomical study of these tissues in thin sections because the lumina of most cells are filled by the opaque colloidal coal substance. In thin section (cross-section) the pericarp is thick (c. $1.2 \mathrm{~mm}$ ) and consists of 3 zones (pl. 5, fig. 1). The outer one is $0.2 \mathrm{~mm}$ thick, opaque, black and without visible cell structure. By examination in reflected light (Ultrapak-method of Leitz) it shows ghost cell structures of flat, thickwalled cells orientated in tangential lamellae much resembling cork tissue. This zone may represent the exocarp, which, e.g. in the recent Trachycarpus martiana (BEGCARI, 1905b, fig. 17), consists of small relatively thick-walled cells with an outer epiderm of extremely thick-walled cells. During incoaling such highly lignified or suberinized tissues will easily be transformed to a massive aggregate by the infilling of the cell lumina with the colloidal humic transformation products of the walls.

Inside this exocarpal zone follows a layer the cell structure of which 
is slightly visible in thin section. The cells are flat, with tangential orientation, the cell walls are thinner than those of the exocarp. Whether the orientation is original or a result of later deformation cannot be proved. This zone, which obviously differs from the outer one, might represent the mesocarp; in Trachycarpus martiana the mesocarpal zone consists of larger cells with thinner walls than those of the exocarp.

In the third or innermost zone most of the cells are strongly dissolved; a lateral longitudinal section of specimen GGU no. 9249.62 indicates that the cells of this zone are flat and thick-walled like those of the exocarpal zone.

Nucellus is coated by a lamina of one cell, locally a few cells. (pl. 10). This is often seen to be adherent to the innermost endocarpal tissue (cf. pp. 18-19) and in this way emphasizes the interior limit of the pericarp. This cell layer, like an epiderm, entirely encloses the nucellus and presumably represents the degenerated testa.

Hence, the pericarp has 3 layers which may be interpreted as exo-, meso- and endocarp.

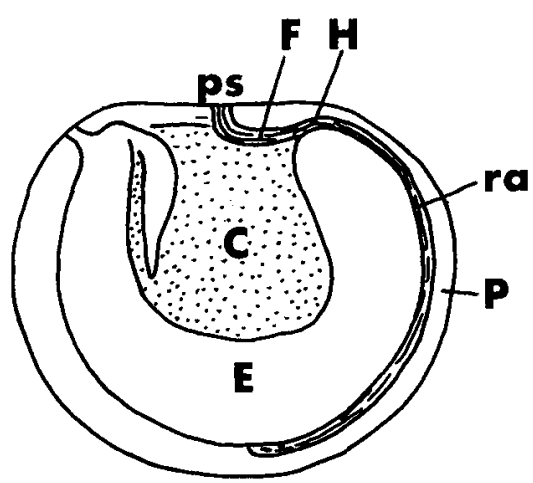

Fig. 6. Coryphoides poulseni n.gen. et n.sp. Generalized sketch showing a lengthsection along the symmetry plane of a fruit. C: columella. E : endosperm. F : funiculus. $\mathrm{H}$ : hilum. P: pericarp. ps: placental scar with the entering petiolar strand, ra: raphe.

About $\times 4$.

\section{Columella}

The term columella is used in this paper for an ingrowth of both the pericarpal and testal tissues (the functional pericarp) along the axis deep into the seed. It might be regarded as a simple kind of rumination.

Under the abscission scar of the pericarp and congruent with this scar we find, on the seed, a similar scar (pl. 1, fig. 1 B, 2B) which represents the base of a big bulbous columella (the placental scar) (pl. 2, fig. $1 \mathrm{~A}$; textfig. 5). In the centre of the placental scar is another, small scar where the primary conducting strand enters the columella. The columella extends half to three quarters of the way along the axis up into the seed. 
The seed axis (textfig. 4) is also the axis of the columella. In length-sections the surface of the columella is not just regular but, generally speaking, its surface is conformable with the surface of the seed. By removing the pericarp of one of the specimens (GGU no. 8179.2) it became possible to orientate the base of the columella on the seed in relation to the abscission scar of the pericarp. Even the central dot in the basal scar of the columella (placental scar) has a corresponding impression in the centre of the abscission scar. On the fossils from which the pericarp is entirely or partly lacking the base of the columella with its central strand is seen even more clearly (GGU nos. 8177 and 9249.64) (pl. 1, fig. 1B).

On such specimens as well as some of the specimens which have been cut into sections the base of the columella appears clearly as a broad, black ring-structure of incoaled matter around the scar of the primary conducting strand. In this paper it is named 'the placental scar'. The axis of the fossil passes through the centre of this scar. The periphery of the placental scar is generally conformable with the circumference of the whole seed, but one clear excentricity occurs. This ring-structure of the seed base has a median peripheral incision (opposite the raphe) (textfigs 3,5 ), which can best be described in analogy with the lip of a jug. This excentric 'lip' contains a short, central length ridge on a single wellpreserved specimen (GGU no. 8173.4) (textfig. 5). The 'lip' is partly filled with incoaled matter like that of the columella of which it is a direct continuation. In this region the cell tissues of the columella directly continue into the pericarp. In contrast to the incoaled filling of the 'lip' structure, the small ridge as well as the 'lip' itself consists, like the whole structure surrounding the columella, of calcified material. The author has not been able to interprete this 'lip' structure. It is situated near to the site of the stylar base seen on other specimens (GGU nos 8179.2; 8179.3; 9249.64) (textfig. 3) and even where the secondary basal strand of specimen GGU no. 8179.2 ends (pl. 1, fig. 3A-B). It can also be seen in lengthsection no. 2 of GGU no. 9249.65 (pl. 5, fig. 2). The small ridge of the 'lip' might be part of the stylar base which is basal-subbasal on some coryphoid palms (e.g. Corypha and Sabal according to Hutchinson, 1959 , p. 667).

From the placental scar the columella stretches into the seed and expands as an extension of the pericarpal tissue into a bulbous structure with subordinate irregularities (textfigs 2,6 ; pl. 2 , figs 1-2). This columella structure penetrates half to three quarters of the way into the seed. This is clearly demonstrated by the thin sections (GGU nos 8173.4; $9249.62 ; 9249.65 ; 9249.66 ; 9249.67 ; 9249.69)$, which are both lengthand cross-sections (pl. 2 ; pl. 3, fig. 4; pl. 4, figs 1-2). It also appears that the surface of the columella (i.e. the boundary surface towards the endosperm) is slightly irregular, though to a varying degree. This may justify 
the use of the term 'simple' rumination to describe the columella structure. The cross-sections (GGU no. 9249.69) show that the columella, like the entire fruit or seed, has its intermediate axis in the median plane and the shortest axis at right angles to this plane i.e. it is oval in cross-section (pl. 2, fig. 2A-B). In the median plane we find a broad ridge on the periphery of the columella, at the raphe side, and opposite a narrow ridge, resulting in corresponding sinuses in the surrounding endospermous structure (pl. 2, fig. 2A-B). Of these median ridges the narrow one in a lateral length-section $(c .1 / 6$ diameter to the side of the median plane)

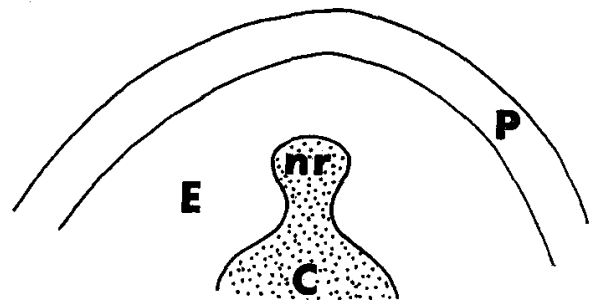

Fig. 7. Coryphoides poulseni $\mathrm{n}$.gen. et n.sp. Sketch showing a detail of the columella in a central cross-section, with the columella structure and its narrow ridge $(\mathrm{nr})$ in the stylar end of the fruit. $\mathrm{C}$ : columella. $\mathrm{E}$ : endosperm. $\mathrm{nr}$ : narrow ridge. P: pericarp.

About $\times 7$.

parallel to the median plane is cut in a way suggesting a tubular connection between the terminal end of the columella and the base of the seed in the region of the stylar base (pl. 2, fig. 1B). Combination of this observation with those of the cross-sections involves a T-shaped crosssection of the narrower columellar ridge (textfig. 7). A similar impressive extension of the columella structure has not been observed in other sections, but considering the minute dimensions of the structure it is unlikely to appear in random sections. On the whole there is full agreement between the length-section of specimen GGU no. 9249.62 (pl. 2, fig. 1A-B) and the cross-section of specimen GGU no. 9249.69 (pl. 2, fig. 2A-B).

\section{The cellular tissues of the columella}

The structure of the columella tissue is so well preserved that we can get an impression of its organization. The columella mostly consists of tubular cells that are 2-4 times longer in length-section than in crosssection. In cross-section these cells are polygonal or circular (pl. 8, fig. 2; pl. 9, fig. 1). A pocket consisting of shorter (equidimensional ?) cells seems to exist centrally in the columella structure. Apart from this central region there is an orientation of the cells seen in length- and cross-sections of the best preserved specimen (GGU no. 9249.62). Along the border 
towards the endosperm we find a palisade of tubular cells with their long axes at right angles to the surface of the columella (or of the endosperm) (pl. 9; pl. 10, figs 1, 3). This palisade has about three cells, the cells being arranged in rows fitting together with their ends, like tube sections. Each cell row (column) seems to have been initiated from one mother cell of a meristem. Each cell filament continues from the periphery into the columella but after about three cells the row turns and the whole filamentous tissue forms a whirl around or into the central non-orientated cell mass (pl. 9, fig. 2). It is not possible in the available sections to follow its whole course continuously, but the cell aggregate seems still to aim towards the base of the columella.

At the columella base a fissure separates the functional pericarp from the seed, (pl. 2, fig. 1A); the cells of the central part of the columella base (the basal surface of the seed) are orientated parallel to this fissure, which may be primary and dependent on this structure. In the periphery of the columella base the cells are tubular and still arranged in filamentous rows. These rows are parallel to the surface of columella (and of the endosperm) and turn over the border of the columella structure (with centrifugal orientation) to connect with the inner pericarpal tissues. The columellar structure is separated from the endosperm of the seed by a membrane of one or two cells thickness (pl. 10, figs 1-2) (see p. 18).

\section{State of preservation of the columella structure}

The original organic structure of the columella is preserved to a varying degree in different specimens. In some fossil specimens almost the entire space of the columella has been replaced by inorganic matter (pl. 7, fig. 3) in which case only the shape of the columella is preserved. At the opposite extreme some specimens have the cellular structure of the entire columella preserved (pl. 2, figs 1-2). Between these extremes are states of preservation with more or less of the original organic structure preserved, with intercallations of secondary, replacive calcite or sedimentary infilling of hollows left by early dissolving of cellular tissue. The secondary calcite may even show recrystallization. When the original cellular structures of the columella are preserved, we find them infiltrated by secondary calcite. In all cases the original tissues had obviously reached an advanced state of decay before the calcification fixed the structure. Usually the mid-lamella of the cell wall only is preserved, but in favourable circumstances an additional lamella may be found. Branching fungal mycelia, simple fungal spores and teleutospores are found in the cells, the fungal spores often crowded together (pl. 13, figs 1-2). This illustrates disintegration by the normal rotting agencies. As mentioned above the fossils demonstrate that disintegration of the columella has 
often advanced so far that the tissue structures are lacking and are even replaced by sedimentary deposits.

Along the periphery of the columella we find a heavily incoaled zone. (pl. 8, fig. 1; pl. 9, fig. 1). This zone consists of a palisade of columnarcylindrical cells in rows; their lumen is filled with opaque, structureless coal substance (pl. 9, fig. 2; pl. 10, figs 1, 3). This resistant cellular layer is found preserved in all specimens, even those where the remaining columella structure has disappeared.

\section{Morphology of the seed}

\section{State of preservation}

The fossil seed consists entirely of a cup-shaped corpus of calcite (pl. 1, figs 1, 2, 3, 7, 8). In the cross-sections it is seen as a white ring around the columella tissues (pl. 2, fig. 2); in the length-sections it is like a white crescent (pl. 2, fig. 1 A; pl. 4, figs 1, 2).

The calcite may be recrystallized into an aggregate of coarse equidimensional units (pl. 4, fig. 2). A primary radiate-globular texture of the calcite is found in some specimens (pl. 4, fig. 1). Only in cases where the calcite is homogeneous are ghost cell-structures preserved (pl. 10, fig. 2; pl. 11, figs 2-3), and yellow particles of organic disintegration products can be found scattered in the calcite structure (pl. 3, fig. 4B; pl. 5, figs $2-3)$, but the latter particles can at least partly represent material displaced from other parts of the fossil by the grinding procedure. Also, very fine, diffuse black particles have been observed which are scattered to form a ghost quadrangular pattern like cellular structures.

\section{Nucellus}

The nucellus consists of a guttiform, cup-shaped endosperm. In the equatorial zone and laterally, on a longitude near to the stylar end of the fruit, a small, simple, saccate embryo penetrates into the endosperm at right angles from the surface (pl. 2, fig. $2 \mathrm{~A} ;$ pl. 12, fig. 1; textfig. 8). The longitude of the embryo is about $135^{\circ}$ dextrally from the raphe when seen from the proximal end.

The whole nucellar structure is coated by a layer of one (to two) cells, which may be interpreted as a rudimentary testa (pl. 10) (see p. 18).

Some of the structures which are found in the calcite corpus interpreted as the endosperm are indisputably cellular and serve as a direct proof of the organic origin of the structure (pl. 11, figs 2-3). The author has found diffuse contours of rounded to rectangular cells. Hence the outermost (peripheral) cellular tissue of the endosperm consists of large 
quadrangular-equidimensional and quite thick-walled cells as seen in length-sections (pl. 10, fig. 2 ; pl. 11, fig. 2). They make up a regular peripheral palisade in the scattered areas where observations can be made. In one of the length-sections of specimen GGU no. 9249.62 even internal cellular structures of the endosperm are visible at some distance from the periphery (pl.11, fig. 3). These cells are also rather thick-walled and arranged in radial rows, i.e. at right angles to the surface of the endosperm. As the figures show, even an arrangement of the cells in radiating

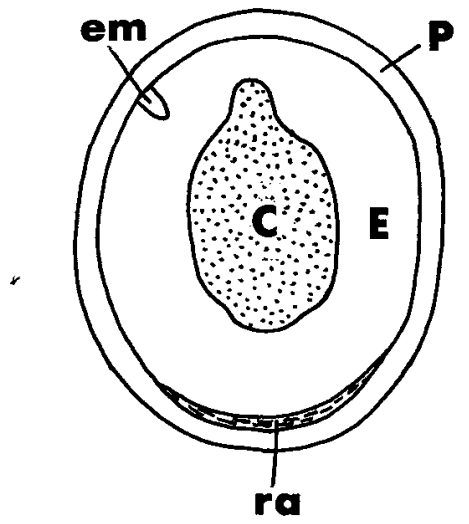

Fig. 8. Coryphoides poulseni n.gen. et n.sp. Generalized sketch showing an equatoria cross-section of a fruit. C: columella with its narrow ridge at the stylar end and its broad ridge at the raphe end. E: endosperm. em: embryo. P: pericarp. ra: raphe.

About $\times 4$.

rows can be inferred. This is supplementary evidence for the interpretation of this calcite structure, according to which, by comparison with recent coryphoid palm seeds (pl. 13, fig. 3B; pl. 14; pl. 15), the structure reproduces the endosperm (p. 24). Hence, most of the volume of the seed consists of a cup-shaped endosperm.

\section{Testa}

The testa is difficult to define exactly because, in this fruit with only one seed, the testa and the pericarp make up one functional, protective structure.

The seed is protected by a coat for which both the testa and pericarp may form part. In the fruit of comparable, recent palms these two components have fused intimately to make this protective structure. This problem is reflected in the following description.

The calcified endosperm structure is enclosed within a membrane consisting of a single cell layer (exceptionally there may be two cells) (pl. 10; pl. 11). This membrane consists of cells which in radial sections 
are flat, rectangular-lenticular (pl. 10, figs 1-2); in tangential sections polygonal, rather equidimensional (quadratic) (pl. 10, fig. 3 ; pl. 11, fig. 1). This is the only tissue which the author definitely regards as testal. On the outside of this there is a layer consisting of a few cells (pl. 10, fig. 2; pl. 11, fig. 2). They are rather thick-walled and resemble cork cells. These cells are filled with opaque, structureless coal. This cork tissue may, at least partly, belong to the testa, because the raphe seems to be in an equivalent position to this layer, but it cannot definitely be excluded, or a part of it, as the innermost endocarpal tissue. A fissure has opened between these two layers except in the area of the raphe, where the strand is external to a 'cork layer'. These cork cells are flatter in the region of the raphe. A similar cellular layer is found external to the raphe.

Distally, the testal zone of the fruit produces special problems.

At the end of the raphean strand (i.e. in the chalaza region), as seen in a median length-section (pl. 5, fig. 3), the presumed testal zone is reproduced in calcite impregnation after advanced disintegration of the tissues. The cellular structure is reproduced, in some cases even cell walls are preserved. Between the one (to two) cell thick membrane surrounding the endosperm and the external 'cork cell layer' a wide zone of rounded cells was recognized of which at least some have originally been thickwalled (pl. 5, fig. 3). This zone corresponds by its thickness to the raphean structure (in its widest sense), conducting cells of which are seen to terminate just near this site. Presumably this tissue represents the distal periphery of the 'chalaza valve' (p. 20) to the raphe side of the 'plug' mentioned below. But, this seems an unreasonable explanation for the corresponding tissue to the opposite side of the 'plug'. Histologically, it might be explained as deriving in the testa and inner pericarp, which in some of the recent coryphoid palm seeds are fused to a functional testa. At the apex of the fruit a circular plug cuts through this structure and expands over the testa layers (pl. 5, fig. 3). This plug shows a totally collapsed tissue, presumably disintegrated by severe fungal attack since fungal spores are densely crowded in the plug. This structure is obvious and characteristic, but its explanation has not been found yet. It may be a disintegrated remnant of a conducting system of the chalaza (the raphean conducting system entering by the chalaza). The idea of a germinating pore cannot be excluded, but then the specimen would belong to another palm genus (p. 27).

\section{Raphe}

The only larger conducting strand which is preserved on the fossil is the raphe. From the centre of the placental scar and through the base of the columella structure we find in the median length-section the dis- 
integrated, but still visible, funiculus (pl. 2, fig. 1 A; pl. 6, figs 1-2). The funiculus leads to the hilum, which the author tentatively places just at the border of the placental scar (the base of the columella). Here the strand enters the testal and endocarpal layers. It is on the opposite side of the placental scar that we find the stylar scar (p. 21). The raphe can be seen in the length-sections to continue exteriorly to the endospermal structure and its testal layer where it follows the testal zone of flat, cork cell-like units. The raphe can be followed to a position just opposite to the centre of the placental scar, i.e. to the distal pole of the fruit (pl. 2, fig. 1A-B; pl. 4, fig. 1; textfigs 2, 6). In a length-section (GGU no. 9249.65) the raphe terminates near to the position of the polar plug of the testaendocarp layer mentioned above (pl. 5, fig. 3). On the surface of the seed structure of the type specimen the raphe is seen like a narrow strand leaving the placental scar in the median plane; gradually it broadens into a circular valve on the side of the seed (pl. 17, fig. 2, textfigs 3,4 ). The periphery of this valve touches the distal pole of the seed (textfig. 3 ). In the terminology of the author this is the 'chalaza valve'.

According to this observation the raphean strand on the periphery of the distal three quarters of the seed, when seen in cross-sections, is found to be a continuous zone of up to $90^{\circ}$ of the seed circumference (pl. 2, fig. 2A-B; pl. 3, fig. 2; textfig. 8). This raphean zone in the crosssections has the long equatorial axis as symmetry axis (i.e. the median plane is symmetry plane of the raphe structure).

In all kinds of sections the raphe appears as a structureless cord which is externally and internally bounded by a thin black rim (pl. 5 , fig. 1 ; pl. 7, figs 1-2, pl. 11, fig. 3). In the structureless calcite of this cord there are remnants of vessels with spiral thickenings, partly in extended groups (pl. 7, figs 1-2). Occasionally the disintegration of the vessels has advanced so far before mineralization that the spirals are fragmentary and in disorder inside this calcite zone. The well-preserved vessels are mostly found along the inner border of the raphe, and here often crowded in groups.

\section{Chalaza valve}

A special raphean structure has been observed in several sections, as mentioned above. At about the equator the raphean strand divides into two branches (or sheets). They follow the external and internal border respectively of a crystalline, lenticular structure of the fossil (pl. 3, fig. 1) which follows in continuation of the normal raphean zone which is obviously thinner. This structure was examined both in length- and crosssections (pl. 3, fig. 1; pl. 3, fig. 4B; pl.12, fig. 2 ; pl. 17, fig. 2). The two branches unite again in the distal (polar) end of the seed. This is the same valve structure which can be recognized on the surface of the seed of the 
type specimen (pl. 17, fig. 2). On this specimen the raphe can be seen leaving the placental scar. At the equatorial zone it broadens into a circular valve the periphery of which touches the distal pole of the seed (textfig. 3). The same structure is visible in cross-section (pl. 3, fig. 1). In the calcite there are scattered ghost cellular contours like those seen in the fossil endosperm structure, though more diffuse and impossible to determine to morphological category. This observation, together with its position with the border touching the distal pole with the chalazean plug, might suggest an aborted seed. An enclosing membrane similar to that around the endosperm (i.e. around the ripe seed) has not been observed around this structure, as could be inferred from this interpretation. Unfortunately this interesting point must remain in doubt. REID \& Chander (1933) mention a similar structure on Palmospermum excavatum in a lateral position, a little more in the basal direction than on Coryphoides poulseni (pl. 16, fig. 3C-D). Reid \& ChandLer designate the structure 'internal chalaza'. The author prefers the descriptive term chalaza valve'.

\section{Stylar scar}

On the calcified seed structure (specimen GGU no. 8179.2) three dark points are situated around a dark papilla approximately equidistant from the latter and with about $120^{\circ}$ divergence (pl. 1, fig. 3A; textfig. 3). In other words, the 3 points are on a circle with its centre in the papilla. Remnants of an equivalent inner series of similar points which are interstitial $\left(60^{\circ}\right)$ in relation to the 3 points just mentioned are suggested by two small spots in the calcite. A similar papilla and 1-2 more diffuse points have been recognized on specimen GGU no. 8179.3; and a diffuse scar of the papilla on GGU no. 9249.64 .

This system of points is just outside the placental scar in the median plane and diametrically opposite to the raphe. In a length-section in the median plane (specimen GGU no. 9249.65) an acute calcite structure can be recognized reaching from the nucellus through the seed coat (testa) and terminating at a point just outside the placental scar (pl. 5, fig. 2). On other fossil seed specimens without testa-pericarp tissues there is at the same place an oblong papilla or ridge (orientation $A-A$ according to the definitions textfig. 4). This ridge is enclosed in the 'lip' structure mentioned above (p. 14 \& textfig. 5).

These observations are in agreement in supporting the idea that we are dealing with a primary structure. The pattern of the points ( $\mathrm{pl}$. 1, fig. $3 \mathrm{~A}$; textfig. 3) reminds us of a flower diagram of a monocotyledon with one stylus and two perianth circles. The position of this structure is just where the stylus is found on certain coryphoid palm fruits with a basal stylus (Hutchinson, 1959, p. 667). 


\section{FUNGAL REMAINS}

In the areas of good preservation (mineralization) there are branched fungal hyphae with visible transverse walls and crowds of small spherical bodies, which may be fungal spores (pl. 13, fig. 1). These are found especially in the columella tissues and the better preserved pericarpal tissues. Even simple germinating spores have been recognized. Biserial teleutospores are rather common (pl. 13, figs 1, 2A-B). These fungal remains are found in tissues which show advanced disintegration of the cell walls.

\section{INTERPRETATION OF X-RAY PHOTOGRAPHS}

The limited number of fossil specimens which are available has reduced the production of thin sections to a minimum absolutely necessary for a reasonable examination. The fossils in question vary concerning the state of preservation, hence, the appearance of the specimens also varies, and this has made it desirable to find supplementary support for the identity between the sectioned specimens and those left untouched. In this situation X-ray photography was employed in the investigation. The $\mathrm{X}$-ray photographs were produced by the Dentological Highschool of Aarhus and the Sedimentological Laboratory of the Geological Department, Aarhus University.

The method depends on the fact that the absorption of X-rays differs greatly for coal and calcite. Thus, it is possible to detect the placental columella which consists largely of incoaled matter. The columella, according to the sections, penetrates into the calcite structure which has replaced the original endosperm. Owing to this contrast details were in some cases reasonably recorded.

The technique made it possible to relegate a single doubtful specimen from the group which was suspected to represent Coryphoides poulseni and to confirm the determination of the remaining specimens (cf. also Coryphoicarpus globoides). The method is illustrated by the pictures of pl. 4 where a number of specimens of Coryphoides poulseni and Coryphoicarpus globoides (pl. 4, figs $3,5,6,8$ ) can be compared with a fossil with a homogeneous structure (pl. 4, fig. 4). The structures are best recorded in specimens with great contrast between coal and calcite bodies. 


\section{COMPARATIVE STUDIES}

\section{Recent genera}

It has not been possible for the author to make a thorough study of the coryphoid palms and the practical restrictions have resulted in a search for sufficient criteria for a reasonable determination of the fossil specimens. During the determination of the fossils an investigation was undertaken of relevant palm seeds from several genera of coryphoid palms. This study was at first based upon the herbarium and carpological collection of the Kew Gardens Herbarium, Kew, England. Later the study was augmented by material presented by several institutions and colleagues. This study of recent palm seeds showed that a number of genera of Corypheae (Hutchinson, 1959, p. 667) (Sabaleae (Engler \& Prantl, 1889)) produce fruits and seeds of the same basic structure as the fossils described above. This applies to the genera Brahea, Corypha, Erythea, Livistona, Sabal, Thrinax, Trachycarpus (pl. 13, fig. 3; pl. 14).

The comparative study involved the following recent species:

Brahea moorei (pl. 14, fig. 7, right)

Chamaerops humilis

Corypha sp. (pl. 14, fig. 3)

Erythea elegans

Erythea sp. (pl. 13, fig. 3; pl. 15)

Livistona altissima (pl. 14, fig. 2)

Livistona australis

Livistona chinensis

Livistona conchichinensis (pl. 14, fig. 4)
Livistona rotundifolia (pl. 14, fig. 1)

Sabal glabra (pl. 14, figs 8-9)

Sabal mexicana

Thrinax floridana (pl. 14, fig. 7, left)

Thrinax keyensis (pl. 14, fig. 6)

Trachycarpus fortunei

Trachycarpus excelsa

Washingtonia filifera

Washingtonia robusta

This inspection of fruits of different coryphoid palms has led the author to the following synthesis:

Among recent coryphoid palm fruits and seeds a characteristic structural type can be distinguished with a certain amount of variation. The basic structure for this group can be described as follows:

The shape of the fruit varies between globular and ellipsoid.

The fruit is l-locular and contains one seed, enclosed by a pericarp of varying thickness, often differentiated into an outer fleshy or fibrous exocarp, and an inner layer of hard tissues. A differentiation into exo-, meso- and endocarp has been demonstrated for Trachycarpus martiana by BECCARI (1905a). In most cases the testa adheres to the pericarp (endocarp); hence, the testa and the pericarp are mostly united into a functional pericarp to form a solid protective structure. When the seed with its protective coat is liberated, the most obvious characteristics of the basic structure are visible (pl. 13, fig. 3A, B; pl. 14; textfig. 9). 


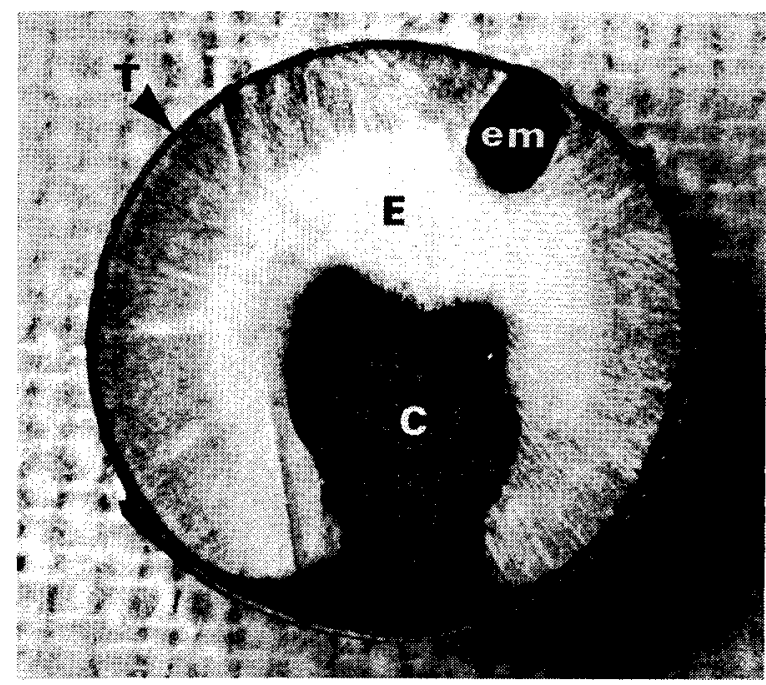

Fig. 9. Livistona australis MART. Length-section through a seed along the plane of symmetry. C: columella. E: endosperm. em: embryo. T: (functional) testa. $\times 6$. Derivation: Kew Gardens Herbarium.

The shape of the seed can be globoid, ellipsoid, discoid or reniform. Proximally there is a big placental scar of varying shape (circular-oval to slit-like). From this scar a placental ingrowth (simple rumination) expands to a varying extent into the seed, and in most variants it extends as a more or less regular bulbous columella deeply into the seed (cf. lengthsection of textfig. 9). The seed is consequently more or less cup-shaped, surrounding this columella or simple rumination. The seed consists of a large often very hard endosperm. A small saccate embryo penetrates from the surface into the endosperm. In most of the coryphoid genera with this type of seed this embryo is situated in the plane of symmetry of the structure. It is the author's impression that the position of the embryo is characteristic for the different genera. Only Corypha has the embryo situated laterally, i. e. outside the plane of symmetry. The author has not been able to make detailed observations concerning the course of the funicular strand and the raphe. The funicular strand in some of the seeds with a large columella winds its way through this structure with a somewhat irregular course (Erythea sp.). On the surface of the seed of some of them a distinct raphe leaves the proximal end of the seed, passes over the border of the placental scar (Erythea sp.) and runs directly towards the distal end, inferring a distal position of the chalaza. A distinct chalaza structure comparable with the chalaza valve of Coryphoides poulseni and the 'internal chalaza' of Palmospermum excavatum (ReID \& Chandler, 1933) has not been observed. It is obvious that the fossil 
fruits and seeds described in this paper coincide well with this description, inferring a near systematic relationship.

\section{Fossil genera}

So far as the author is aware the only fossils described earlier that are obviously related to Coryphoides poulseni are the fossil coryphoid palm seeds described by Reid \& Chandier (1933) from the Eocene London Clay. From the excellent illustrations (ibid. 1933, pl. 1, figs 13-39) the similarity of the Eocene species to the author's fossils from the Upper Danian of West Greenland is striking. The size and shape of the fossils is about the same. They have the same characteristic 'columella', syno-

\section{Table 1.}

Comparison between Palmospermum excavatum Reid \& ChandLeR and Coryphoides poulseni n. gen. et n. sp.

\begin{tabular}{|c|c|c|}
\hline & Palmospermum excavatum & Coryphoides poulseni \\
\hline Size & Max. diameter about $9-15 \mathrm{~mm}$ & $\begin{array}{l}\text { Max. diameter } 7.4-9.2 \\
\text { mm }\end{array}$ \\
\hline Shape & Sub-globular & Sub-globular \\
\hline Placentation & $\begin{array}{l}\text { Placental scar oblong, slit-like } \\
\text { with a shallow prolongation in } \\
\text { the raphe side, a narrow prolon- } \\
\text { gation in the opposite side. }\end{array}$ & $\begin{array}{l}\text { Placental scar circular } \\
\text { with a narrow prolon- } \\
\text { gation to the stylar side } \\
\text { (opposite to the raphe). }\end{array}$ \\
\hline $\begin{array}{l}\text { Placental columella } \\
\text { (= ventral depres- } \\
\text { sion) }\end{array}$ & $\begin{array}{l}\text { In the symmetry plane: some- } \\
\text { what oblique (?) in relation to } \\
\text { the axis of the seed (according to } \\
\text { X-ray photography). }\end{array}$ & $\begin{array}{l}\text { In the symmetry plane: } \\
\text { symmetry axis of placen- } \\
\text { tal columella = axis of } \\
\text { the seed. }\end{array}$ \\
\hline $\begin{array}{l}\text { Entrance of conduc- } \\
\text { ting strand }\end{array}$ & Central in the placental scar. & $\begin{array}{l}\text { Central in the placental } \\
\text { scar. }\end{array}$ \\
\hline $\begin{array}{l}\text { Position of stylar } \\
\text { scar }\end{array}$ & $\begin{array}{l}\text { No stylar scar seen on the basal } \\
\text { part, position unknown }\end{array}$ & $\begin{array}{l}\text { Basal, outside placenta, } \\
\text { opposite raphe. }\end{array}$ \\
\hline Position of embryo & $\begin{array}{l}\text { On the basal half-sphere, about } \\
135^{\circ} \text { dextrally from the raphe end } \\
\text { of the symmetry plane when seen } \\
\text { from the proximal end. }\end{array}$ & $\begin{array}{l}\text { Equatorial about } 135^{\circ} \\
\text { dextrally from the raphe } \\
\text { end of the symmetry plane } \\
\text { when seen from the prox- } \\
\text { imal end. }\end{array}$ \\
\hline $\begin{array}{l}\text { Chalaza valve } \\
\text { (= internal chalaza) }\end{array}$ & $\begin{array}{l}\text { Touching the broad raphean ridge } \\
\text { of the placental columella, not } \\
\text { reaching the distal pole. }\end{array}$ & $\begin{array}{l}\text { Begins well above the base } \\
\text { of the placental columella, } \\
\text { touches the distal pole. }\end{array}$ \\
\hline
\end{tabular}


nymous with the 'ventral depression' of ReId \& Chandeer. The 'internal chalaza' of Reid \& Chander $\mathrm{R}$ is also found on Coryphoides poulseni.

These related species from the London Clay are all referred to coryphoid palms. Like most of the recent genera of the Corypheae (pl. 13, fig. 3 B; pl. 14, figs 2, 4, 5, 6, 7, 9) (except Corypha, pl. 14, fig. 3) most of the London Clay species which are similar to Coryphoides poulseni have the embryo situated in the plane of symmetry of the seed. On one species that resembles Coryphoides poulseni, Palmospermum excavatum, Rein \& Chanderr (1933) had not found the embryo. The author has studied the type specimens of Palmospermum excavatum and found the position of the embryo (pl. 16, fig. $3 \mathrm{~A}, \mathrm{~B}, \mathrm{C}$ ). The result of the study is shown in table 1 in comparison with Coryphoides poulseni.

The two species are comparable in shape, the main course of the conducting strand and the over-all coryphoid structure including the characteristic columella are the same. Even the 'chalaza valve' is found on both.

Unfortunately the important factor of the position of the stylar scar is unknown for Palmospermum excasatum.

On the other hand, the seeds differ in a number of features: size, shape of columella ('ventral depression' of REID \& CHANDLER), and shape of the placental scar (base of columella), position of the 'chalaza valve' ('internal chalaza' of Reid \& CHANDLER), and the position of the embryo. It is interesting that the embryo is on about the same longitude although on a different latitude. The author regards the position of the embryo as a character of diagnostic value at a generic level: on Palmospermum excavatum the embryo is on the proximal hemisphere, on Coryphoides poulseni it is equatorial and on a seed from the Kew Gardens Herbarium labelled Corypha? the author found it on the distal hemisphere. These are the only three coryphoid genera with the embryo situated outside the plane of symmetry, so far as the author is aware.

Hence, it seems reasonable to erect a new genus based on the Greenland fossils, particularly as the position of the stylar scar has not been recognized on Palmospermum excavatum.

\section{Taxonomic conclusion}

Among the recent genera investigated seeds with the same type of columella as Coryphoides poulseni were found in Brahea, Corypha, Erythea, and Livistona (pl. 13, fig. 3 B, pl. 14).

The fossils investigated demonstrate that the fruit of Coryphoides poulseni had a basal stylus. This characteristic feature is found among the investigated genera only in the genus Corypha according to Hutchinson, 1959, p. 667). On the other hand, the fossils differ from all the related 
recent palm seeds in the position of the embryo. In Brahea, Erythea, Livistona and Thrinax, and the less similar seeds of the coryphoid genera Chamaerops, Trachycarpus, Washingtonia, the embryo is situated in the median plane (i. e. the symmetry plane of the normal, bilaterally symmetrical seeds). In Coryphoides poulseni the embryo has a lateral position in the equatorial zone of the seed, and on the hemisphere opposite to that of the raphe. Also in Corypha the embryo is situated outside the median plane (lateral), but in this case in the distal hemisphere.

In the coryphoid genera which the author has studied the proportion between the columella and the endosperm, the shape of the columella and the position of the embryo in the endosperm seem relatively stable and constant within each genus, and characteristic for each genus. The comparative studies have resulted in the establishment of a new genus for the fossil coryphoid seeds from the Upper Danian of the Agatdalen area: Coryphoides, based on the same criteria.

The fossil fruits of Coryphoides poulseni show a pericarp of three layers, which may be referred to as exo-, meso- and endocarpal units. A similar triple division has been illustrated for Trachycarpus by BEcGari, 1905 a, figs 17 and 18.

In conclusion it can be stated that there is good evidence for placing our new genus in the family Palmae, tribe Corypheae. 


\section{CORYPHOICARPUS}

n. gen.

\section{Diagnosis}

Small coryphoid palm seed with the following characteristics: Seed (fruit) globular with small placental scar. Diameter of the seed about 7.5 $\mathrm{mm}$. From the placental scar a large, bulbous, somewhat irregular columella expands into the seed. The seed is cup-shaped with its hollow corresponding to the shape of the columella. Long raphe stretching in the plane of symmetry longitudinally from the placental scar towards the distal pole. The chalaza (the terminal point of the raphe) is found $30^{\circ}-45^{\circ}$ from the distal pole. Hence, the ovule was campylotropous. The saccate embryo penetrates into the endosperm from the surface at about $90^{\circ}$ dextrally from the raphe in the equator zone.

\section{CORYPHOICARPUS GLOBOIDES \\ n. gen. et $\mathrm{n}$. sp.}

(Textfig. 10; pl.4, fig. 8A-B; pl. 16, fig. 1A-C; pl. 18).

Holotypus: the specimen GGU no. 20166.

Locus typicus: Danienkløft, Tunorssuaq, central Nûgssuaq (textfig. 1, point 4).

Stratum typicum: The beds of the Propeamussium Member (Rosenkrantz, 1970) exposed in 'the north section' of Danienkløft, Tunorssuaq. Lower Danian.

\section{Diagnosis}

Coryphoid palm fruit (seed) with the following characteristics: Seed globular with small, basal, slightly excentric, circular placental scar in the centre of which is found the scar of the conducting strand which enters the fruit from the pedicel. The ratio between the diameter of the placental scar and the diameter of the seed is about 0.37. From the central scar a funicular strand penetrates into the basal part of the columella making a loop within the plane of symmetry and returning to the basal surface at 


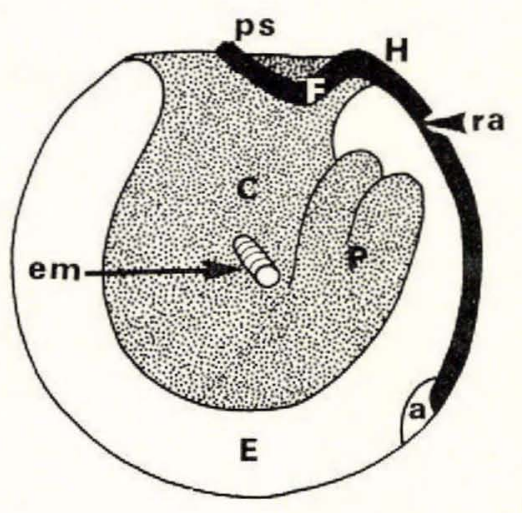

A

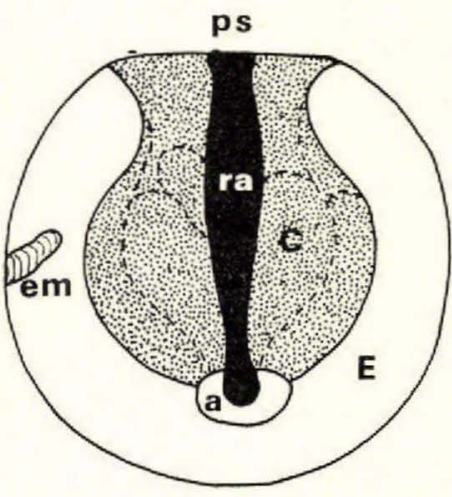

B

Fig. 10. Coryphoicarpus globoides n.gen. et n.sp. Sketches drawn after X-ray photographs showing length-projections parallel to (A) and at right angles to (B) the plane of symmetry. a: chalaza. C: columella. E: endosperm. em: embryo. F: funiculus. H: hilum. P: 'reversed pocket' of columella. ps: placental scar. ra: raphe. About $\times 8$. Original $\mathrm{X}$-ray photographs are found on pl. 18 .

the border of the placental scar i.e. at the hilum. From the hilum it proceeds longitudinally in the plane of symmetry to the oval chalaza which is found at an angle of $30^{\circ}-45^{\circ}$ from the distal pole. From the placental scar a large, bulbous columella expands deeply into the seed where it produces a reversed somewhat irregular pocket (see pl. 4, fig. 8B; pl. 18, fig. 1 and the explanatory textfig. 10) at the raphe end of the seed. The endospermous structure is like a rather thin bowl and surrounds the columella. The embryo is a small, saccate, conical structure stretching from the surface of the seed obliquely far into the endosperm. It is situated in the equatorial zone of the seed about $90^{\circ}$ dextrally from the raphe. The seed has been enclosed by a pericarp.

\section{Description of the fossil}

Coryphoicarpus globoides is based on a single well-preserved specimen from a concretion from the black bituminous shale of the ravine called Danienkløft, leading a tributary brook from the north into the Tunorssuaq valley (textfig. 1, point 4). It was found in the so-called 'north section' of Rosenkrantz (1970).

Only one specimen is available. Professor Rosen krantz's large collection of fossiliferous concretions from the marine Danian may well yield 
more specimens and in the meantime the author has not made any thin section. Hence, the description is based on the outer morphology and $\mathrm{X}$-ray photographs, including stereographic X-ray photographs. Even with this restriction the fossil specimen shows sufficient characteristics to establish a new taxonomic unit and to refer it to the coryphoid palms.

\section{State of preservation}

The fossil is so like the fossil seed structure of Coryphoides poulseni (p. 7) that its interpretation can be supported by the experience gained from the study of the latter species.

On the surface are remnants of an incoaled surrounding sheet, the pericarp. The fossil is preserved by mineralization, but judging from the $\mathrm{X}$-ray photographs (pl. 4, fig. 8A-B) the columella (see below) consists of material with a different absorption of X-rays. According to similar reactions from fossils belonging to Coryphoides poulseni the columella might be incoaled, although the placental scar shows a higher degree of mineralization: a combination of calcite and coal is assumed.

\section{Morphology}

The general resemblance to the seed structure of Coryphoides poulseni and the recent genera with similar seeds allows us to regard the fossil seed in question as belonging to a coryphoid palm.

The surface of the seed shows incoaled remnants of a pericarp. The seed is subglobular, almost spherical. There is a slight difference in length between the two equatorial axes, the longest axis following the symmetry plane (textfig. 4).

Basally, and slightly excentric, there is a circular scar, a placental scar, being the base of a columella (pl. 16, fig. 1B). In the centre of the placental scar is found a smaller scar where the conducting strand enters the fruit from the pedicel (pl. 16, fig. 1 B-C). From this point the impression of a narrow band follows the symmetry plane over the border of the placental scar and continues in a delicate ridge longitudinally into the region of the distal pole (pl. 16, fig. 1C). This structure is magnificently recorded on the X-ray photograph as a distinct, rather wide band (pl. 4, fig. $8 \mathrm{~A}$; pl. 18, figs $2-3$; textfig. 10). No doubt this structure represents the funicular strand from the centre of the placental scar to its border. On the stereographic X-ray photographs parallel to the plane of symmetry (pl. 18, fig. 1) the funicular strand is seen to penetrate into the basal part of the columella. The strand makes a loop in the plane of symmetry and returns to the basal surface at the border of the placental scar. 
The latter area on the basal surface is the hilum. From the hilum the strand, representing the raphe, proceeds longitudinally in the plane of symmetry to the chalaza.

In the middle, at the raphe side, crossing the equatorial zone of the spherical seed and stretching over its distal end, there is a faintly valvate structure (pl. 16, fig. 1 A, 1C). The surface of the fossil has a suggestion of a shallow, diffuse dome at this place. The raphe is included in this structure and is partly absorbed by it. No anatomical investigations have been made, and so far it is not possible definitively to determine whether it corresponds to the chalaza valve of Coryphoides poulseni and Palmospermum excavatum. But it neither partly covers nor has a similar shape or similar dimensions to the chalaza structure as the latter appears on the X-ray photographs.

The position of the chalaza has been found by combined study of the stereographic X-ray photographed length-projections (pl. 18; textfig. 10). Hence, the position of the chalaza is in the plane of symmetry $30^{\circ}-45^{\circ}$ from the distal pole. On the X-ray photographed length-projection at right angles to the plane of symmetry the chalaza appears like a small oval around the distal end of the raphe strongly contrasting with the latter (pl. 18, fig. 2; textfig. 10 B). This structure is probably comparable with the chalaza valve of Coryphoides poulseni rather than the above mentioned valvate structure on the surface of the seed in the equatorial region.

The position of the chalaza implies a derivation of the seed from a campylotropous ovule.

The length-section $\mathrm{X}$-ray photographs reveal an internal structure equivalent to the placental columella of the seed of Coryphoides poulseni (p. 13). This structure is relatively large, irregularly bulbous, the irregularity being a reversed pocket situated at the raphe end of the seed (pl. 4, fig. 8B; pl. 18, fig. 1). On X-ray photographs this pocket shows some peripheral irregularities. The columella structure can be studied in detail on the stereographic X-ray photographs, especially on the projection parallel to the plane of symmetry (pl. 18, fig. 1; textfig. 10A).

The endosperm seems to be a rather thin sheet surrounding the columella.

The embryo has been found and its position determined by combined study of stereographic X-ray photographs in three projections at right angles to each other (pl. 18). The study of these projections demands some individual training with the stereoscope as well as familiarity with the structure of Coryphoides poulseni. The saccate embryo structure is best recognized on the projection at right angles to the plane of symmetry, where it is seen in a positive photographic representation like a small dark projection from the surface of the endosperm in the equatorial 
zone, pointing obliquely into the seed in the direction of the placental scar.

On the X-ray projection parallel to the equatorial plane the embryo is more diffuse, but it is marked by a black lining along one side of the small saccate structure projecting from the surface into the seed. It is more difficult to identify the embryo on the X-ray projection parallel to the plane of symmetry, which is necessary for the determination of its 3-dimensional position. On this projection the endosperm structure interferes with the image of the columella. At least two small 'knobs' which may represent the embryo are found. When the observer has adjusted his eyes to the stereographic effect, concentration on the image of the upper surface region of the seed shows a small, double ring-structure situated in the centre of the picture. Its position fits well with the observations on the other stereographic X-ray photographs. Hence, the saccate embryo touches the surface of the seed in the equatorial zone at about $90^{\circ}$ dextrally in relation to the raphe end.

\section{Discussion}

The fossil described above shows the same over-all structural pattern of fruits and seeds of coryphoid palms of the genera Livistona, Corypha, Erythea, Thrinax, Brahea, etc. (pl.13, fig. 3; pl. 14-15) and the fossil genus Coryphoides: a globular fruit containing one characteristic seed inside a rather thin pericarp. This seed is approximately globular with a proximal circular scar, from which a large bulbous placental columella penetrates into the seed. The seed surrounds the columella as a bowlshaped structure. By analogy with Coryphoides poulseni it can be interpreted as consisting mainly of an endosperm. The embryo is a small saccate structure inserted in the endosperm. These facts leave little doubt that we are dealing with the fruit and seed of a coryphoid palm.

The precise determination of the fossil depends on the details of the characters mentioned above: the columella, the placental scar, the embryo, and also on the raphe and the chalaza including the problem of the chalaza valve. A decision must be taken on the two following problems: 1) the relation of Coryphoicarpus to the various coryphoid palms; 2) the relation of Coryphoicarpus to Coryphoides poulseni and Palmospermum excavatum.

Among the coryphoid palms the relatives of Coryphoicarpus must be sought in the group of genera with seeds having a deeply penetrating, rather elaborate and somewhat irregular columella. This is found among the genera which have already been treated in the discussion of the relationship of Coryphoides poulseni (p. 26). Concerning this group of 
coryphoid palms, the author regards the position of the embryo as a distinctive generic character, especially when evaluated in combination with the shape and elaboration of the columella structure. Coryphoicarpus can be distinguished from most of the coryphoid palms in question because the embryo is situated outside the plane of symmetry of the seed, a character which it shares only with the extant genus Corypha, and the fossils Coryphoides poulseni and Palmospermum excavatum, as far as the author is aware. Coryphoicarpus is easily distinguished from the recent genus Corypha, and the fossils Palmospermum excasatum and Coryphoides poulseni by the position of the embryo and from the fossil species mentioned by the more elaborate columella with the 'reversed pocket' and by the lack of a large, distinct chalaza valve. The embryo is also relatively larger and the endosperm less extensive (thinner) on the Coryphoicarpus seed. In this connection, the relatively smaller, oval placental scar is also distinct from the relatively larger scar on Coryphoides and the more slit-like placental scar of Palmospermum excavatum. Coryphoicarpus differs from the recent Corypha in the position of the embryo, which is equatorial in the former. The seed material of the recent Corypha which was available during the author's study does not allow a critical all-round comparison, but some more distinct supplementary differences were found concerning the position of the chalaza, the columella structure and the extent of the endosperm. On Corypha the chalaza seems to be on the basal half of the seed, i.e. the raphe is short; on Coryphoicarpus the chalaza is distal and the raphe consequently long. The columella of the seeds of Corypha is distinctly simpler than the irregular, relatively complicated structure of Coryphoicarpus, and the endosperm of Corypha is relatively larger than that of the seed of Coryphoicarpus.

Despite the restrictions of the comparative study of Corypha it seems reasonable to keep the new fossil separate from the related recent genera as well as from Coryphoides poulseni and Palmospermum excavatum and to establish it as a new genus. Hence the fossil in question is named Coryphoicarpus globoides.

\section{Taxonomic conclusion}

According to the above discussion, the described fossil fruit is regarded as belonging to a palm. Systematic position: Palmales, tribe: Corypheae in sensu Hutchinson, 1959 and Engler \& Melchior, 1964. 


\section{PROBABLY SYNCHRONOUS PALM LEAVES}

In West Greenland, in deposits synchronous with those which contained Coryphoides poulseni, fragmentary fossil leaf remains have been found previously and determined as Palmae. Some of the best fragments were described by HeEr (1883) under the designation of Flabellaria groenlandica (ibid. p. 69 and pl.68, figs 5-7-the present paper pl. 17, fig. 1). The types of Heer are from 'Upper Atanikerdluk A' i.e. the Quikavsak Member, which the author (Косн, 1959, 1963) referred to the Lower Paleocene and which according to Rosenkrantz (1970) belongs to the Upper Danian. The Quikavsak Member of Atanikerdluk is synchronous with the Sonja Member and the Turritellakloft Member of Agatdalen, central Nûgssuaq (Косн, 1959), the locality of Coryphoides poulseni.

The author's collection from the Quikavsak Member, Atanikerdluk contains similar but smaller fragments, as do the collections of the Mineralogical Museum, University of Copenhagen. A number of good fragments are in the collection made by the Second Dicksonian Expedition to Greenland 1883 which belongs to Naturhistoriska Riksmuseet (Department of Palaeobotany), Stockholm.

In the author's opinion there is little doubt that the type specimens of HEER (1883) and a number of specimens from the cited collections are fragments of fan-shaped leaves with a monocotyledonous nervation. Some of the specimens demonstrate a relief undoubtedly comparable to the well known sharply folded pattern of the leaves of the fan palms. They were found in fluviatile sediments, and therefore have undergone transport and deposition in turbulent and well aerated water, a situation unfavourable for preservation. When, despite these conditions, some specimens are impressions with clear cut relief we must conclude that they were resistant leaves like the extant fan palms. The dimensions are similar to those of the recent palmetto (Sabal palmetto). The specimens are probably fragments of small leaves of a fan palm, especially in the light of the discovery of Coryphoides poulseni, but in the author's opinion the conclusive evidence is still lacking.

Lamotre (1952) in his 'Catalogue of Cenozoic Plants of North America' changed the generic name to Exflabellaria (STERNBERG) since an extant genus of this name was found to have priority. The Greenland species consequently must be Exflabellaria groenlandica (HEER) LAMOTTE. 


\section{ACKNOWLEDGEMENTS}

This study was supported by Statens Almindelige Videnskabsfond (the Danish State Science Foundation) and the Carlsberg Foundation, and by grants from the universities of Copenhagen and Aarhus.

The facilities provided by the Paleobotanisk Avdelning, Naturhistoriska Riksmuseet, Stockholm and the help of staff during repeated visits are gratefully acknowledged. Especially, gratitude is expressed to the former head of the Paleobotanisk Avdelning, Professor O. H. Selling, for his inspiring and positive attitude to the work, of which essential steps were carried out with his support. The technician of the Paleobotanisk Avdelning, preparator K. E. Samuelsson ingeniously made a series of large thin sections of difficult fossils and was of great help with many problems.

During my visit to the British Museum, Natural History, London in 1954 I remember the late Keeper Dr. N.W. Edwards for his kind support. During this visit the author discussed the fossil seeds of this publication with Dr. M.E. J.ChANDLER and the advice received during that meeting has been of great help to the present investigation. The author wishes to express his gratitude.

The author has borrowed palm seeds and studied palm seeds in the collections of the Kew Gardens Herbarium and collected materials for comparative study in Kew Gardens. For this valuable support to my study I am much obliged to the Director of the Royal Botanic Gardens, Kew, Sir George Taylor and to Dr. T. Hubbard and Dr. E.MilneREDhEAD of Kew Gardens Herbarium.

Several colleagues and institutions have kindly assisted me during the investigations:

Dr. A.Skovsted, Botanical Museum, University of Copenhagen, has currently supported my study by placing the collections at my disposal and securing new specimens for me.

Collections of palm seeds have been sent to the author from:

Botanical Garden, University of California, USA.

Department of Biological Science, Florida State University, USA.

Dr. S. Hatrori, The Hattori Botanical Laboratory, Japan. 
Dr. Stanley C. Kiem, Fairchild Tropical Garden, Miami, USA.

Dr. H. E.Moore. Jr., Bailey Hortorium, Cornell University, USA.

Dr. T.Satake, Hiroshima-ken, Japan.

Professor O. H. Sellivg, Djursholm, Sweden.

Dr. E. Leland Webrer, Chicago Natural History Museum, USA.

Dr. E. Ratjen and dr. T. Troest, Dentological Highschool, Aarhus and professor Gunnar Larsen, Geological Department, Aarhus University made possible my experiments with $\mathrm{X}$-ray photography by placing their X-ray laboratories at my disposal.

The photographer of my laboratory, Mr. John Sommer, has made a number of the illustrations. Dr. W.L.Friedrich and Dr. A.R.Lond were kind enough to read and correct the manuscript.

The author expresses his sincere thanks to all of them.

This paper is published with the permission of the Director, Geological Survey of Greenland.

Phytopalaeontological Section,

Geological Institute

Aarhus University

Ole Worms Alle,

8000 Aarhus C, Denmark 


\section{SELECTED BIBLIOGRAPHY}

Beccari, O. 1905a: Le palme del genera 'Trachycarpus'. Webbia 1, 41-68.

BecCARI, O. 1905b: Note anatomiche sul frutto del Trachycarpus. Webbia 1, 68-72.

Вомнавd, M. L. 1951: Palm trees in the United States. Agriculture Inf. Bull. 22, $26 \mathrm{pp}$.

Chandler, M. E. J. 1961: The Lower Tertiary floras of southern England I: Paleocene floras, London Clay flora (Supplement). London: British Museum (Natural History). $354 \mathrm{pp}$.

ChandLER, M. E. J. 1962: The Lower Tertiary floras of southern England II: Flora of the Pipe-Clay Series of Dorset (Lower Bagshot). London: British Museum (Natural History). $176 \mathrm{pp}$.

GHANDLER, M. E. J. 1963: The Lower Tertiary floras of southern England III: Flora of the Bournemouth Beds, the Boscombe, and the Highcliff Sands. London: British Museum (Natural History). 169 pp.

ChANDLER, M. E. J. 1964: The Lower Tertiary floras of southern England IV: A summary and survey in the light of recent botanical observations. London: British Museum (Natural History). $151 \mathrm{pp}$.

Corner, E. J. H. 1966: The natural history of palms. Weidenfeld \& Nicolson, London, $393 \mathrm{pp}$.

Dahlgren, B. E. 1936: Index of American palms. Publs Field Mus. nat. Hist, Bot. Ser. 14, $456 \mathrm{pp}$.

Engler, A. \& Melchior, H. 1964: Syllabus der Pflanzenfamilien 2. 12 Aufl. Berlin. 666 pp. (Corypheae 583-584).

Engler, A. \& Prante, K. 1889: Die natürlichen Pflanzenfamilien $2^{3}$. Leipzig, $168 \mathrm{pp}$.

HeEr, O. 1883: Flora Fossilis Groenlandica. Flora Fossilis Arctica 7. Zürich, 275 pp.

Hutchinson, J. 1959: The families of flowering plants. 2: Monocotyledons. 511-792, 2nd edit. Oxford Univ. Press.

Kосн, B. E. 1959: Contribution to the stratigraphy of the non-marine Tertiary deposits on the south coast of the Nûgssuaq peninsula, Northwest Greenland. With remarks on the fossil flora. Bull. Gronlands geol. Unders. 22 (also Meddr Gronland 1621), $100 \mathrm{pp}$.

Kосн, B. E. 1963: Fossil plants from the Lower Paleocene of the Agatdalen (Angmartussut) area, central Nûgssuaq peninsula, Northwest Greenland. Bull. Grønlands geol. Unders. 38 (also Meddr Gronland 1725), $120 \mathrm{pp}$.

Косн, B. E. 1964: Review of fossil floras and nonmarine deposits of West Greenland. Bull. geol. Soc. Amer. 75, 535-548.

Косн, B. E. 1967: To velbevarede fossile nødfrugter fra Agatdalens Paleocæn, Nûgssuaqhalvøen, Nordvestgrønland. Meddr dansk geol. Foren. 17, 155-159.

Koch, B. E. \& Friedrich, W. L. (in press): Stereoskopische Röntgenaufnahmen von fossilen Früchten. Bull.geol. Soc. Denm. 214. 
Lamotte, R. S. 1952: Catalogue of the Cenozoic plants of North America through 1950. Mem. geol. Soc. Amer. 51, $381 \mathrm{pp}$.

Mowry, H. 1931: Native and exotic palms of Florida. Bull. Univ. Florida Experiment Station 228, $71 \mathrm{pp}$.

Nó́, A. G. 1936: Index of American palms: fossil palms. Publs Field Mus. nat. Hist., Bot. Ser. 14, 456 pp.

Reid, E. M. \& Chander, M. E. J. 1933: The London Clay flora. London: British Museum (Natural History). $561 \mathrm{pp}$.

Rosenkrantz, A. 1970: Marine Upper Cretaceous and lowermost Tertiary deposits in West Greenland. Meddr dansk geol. Foren. 19, 406-453.

Rosenkrantz, A. \& Pulvertaft, T. C. R. 1969: Cretaceous-Tertiary stratigraphy and tectonics in Northwest Greenland. Mem. Amer. Ass. Petrol. Geol. 12, 883898.

Sargent, C. S. 1921: Manual of the trees of North America. 2nd edit. 910 pp. Boston $\&$ New York.

SmalL, J. K. 1931: Palms of the continental United States. Sci. Monthly 32, 240255.

Tomurnsson, P. B. 1961 : Anatomy of the Monocotyledons, II Palmae. Oxford. $345 \mathrm{pp}$ 


\section{PLATES}

The label numbers quoted in the explanations to the plates refer to the following localities:

Agatkløft (fig. 1, loc. 1): 8177 .

Qaersutjægerdal, big section (fig. 1, loc. 3): 8173, 8179, 28955.

Turritellakløft (fig. 1, loc. 2): 8172, 9249.

Danienkløft, Tunorssuaq (fig. 1, loc. 4): 20166.

Unless otherwise stated the photographs are the work of the author.

The depicted specimens will be kept in the National Type Collection of the Mineralogical Museum, University of Copenhagen, Denmark. 


\section{Plate 1}

Fig. 1 A: Seed cast in lateral view; the symmetry plane is parallel to the plate. The flat bottom is the placental scar. $-\times 2.5$. GGU no. 9249.64. Loc. Scaphitesnæsen.

Fig. 1 B: The base of the same seed with the placental scar. (columella base); axial view. $-\times$ 2.5. GGU no. 9249.64. Loc. Scaphitesnæsen.

Fig. 2 A: View along the plane of symmetry. The stylar end. Corroded seed. $-\times \mathbf{3}$. GGU no. 8177. Loc. Agatkløft: big section.

Fig. 2 B: The proximal end with the placental scar (columella base); axial view. Corroded seed. $-\times$ 3. GGU no. 8177. Loc. Agatkløft: big section.

Fig. 3 A: View from the stylar end along the plane of symmetry. The stylar papilla with a scar surrounded by 3 smaller scars. Seed, after the removal of the pericarp and testa. $-\times 2.5$. GGU. no. 8179.2. Loc. Qaersutjægerdal: big section.

Fig. 3 B: The proximal end with the placental scar (columella base); axial view. Seed, after the removal of the pericarp and testa. $-\times 2.5$. GGU no. 8179.2. Loc. Qaersutjægerdal: big section.

Fig. 4: Small corroded seed with a remnant of the pericarp of the placental region adhering to the structure. $-\times 2$. GGU no. 9249.70. Loc. Scaphitesnæesen.

Fig. 5: The specimens of figs 1-4 and 6 at about natural size.

Fig. 6 A: Complete fruit, (somewhat compressed) viewed obliquely from below: Placental end with abscission scar. $-\times 2.5$. GGU no. 9249.63. Loc. Scaphitesnæsen.

Fig. 6 B: Base of the same specimen with abscission scar and scar left by the entering petiolar strand (black dot in centre). $-\times 2.5$. GGU no. 9249.63. Loc. Scaphitesnæsen.

Fig. 7: Half of the cast of a seed surrounded by incoaled remnants of pericarp in sandstone. $-\times$ 2.4. GGU no. 28955.42. Loc. Qaersutjægerdal: big section.

Fig. 8 A: Complete seed: View along the plane of symmetry; raphean end. Abscission scar downwards. $-\times 2.5$. GGU no. 9249.64. Loc. Scaphitesnæsen.

Fig. 8 B: Complete seed. Axial view towards distal end. $-\times 2.5$. GGU no. 9249.64. Loc. Scaphitesnæsen. 


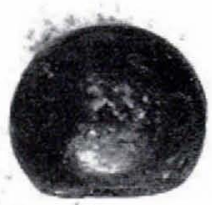

$1 \mathrm{~A}$

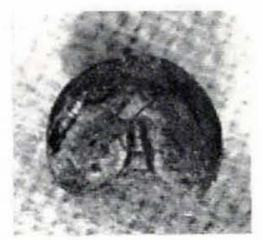

$2 \mathrm{~A}$

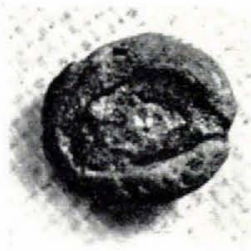

2 B

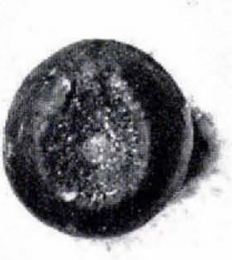

$1 \mathrm{~B}$

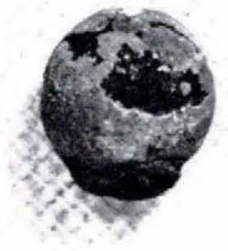

4
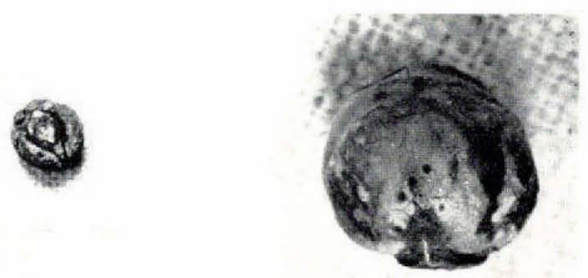

$3 \mathrm{~A}$

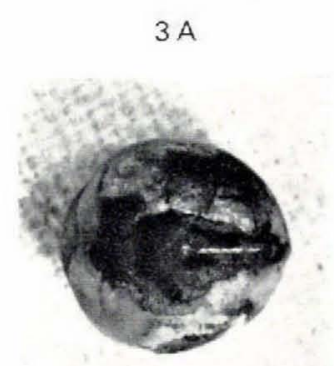

$3 \mathrm{~B}$
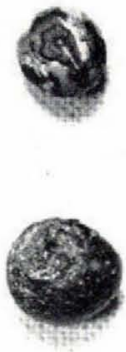

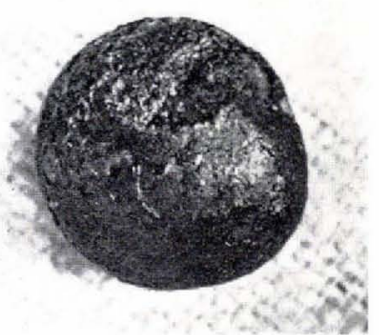

$6 \mathrm{~A}$

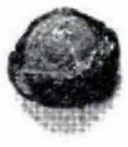

5

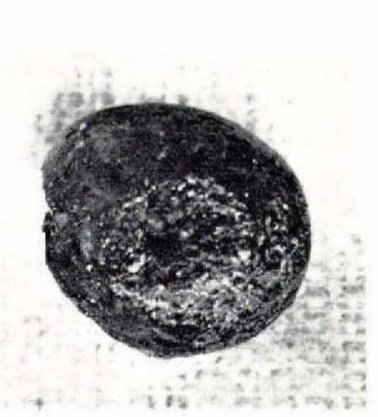

$6 \mathrm{~B}$

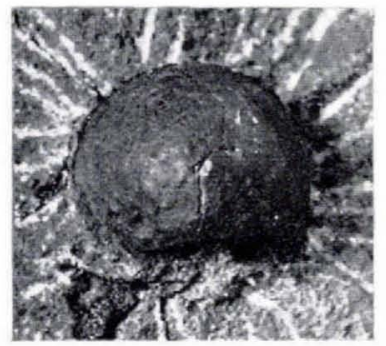




\section{Plate 2}

Coryphoides poulseni n. gen. et $\mathbf{n}$.sp.

Fig. 1 A: Length-section of a fruit along its symmetry plane. P: pericarp. pl: placenta. $\mathrm{N}$ : nucellus. $\mathrm{G}$ : columella. ra: raphe. The raphe is seen along the lower side of the nucellus. $-\times 6.5$. GGU no. 9249.62 (thin section 1). Loc. Scaphitesnæsen.

Fig. 1 B: A lateral length-section parallel to the symmetry plane of the same specimen as fig. $1 \mathrm{~A}$. The raphe is along the upper side of the nucellus with the section viewed in the opposite direction to fig. $1 \mathrm{~A} .-\times 6.5$. GGU no. 9249.62 (thin section 2). Loc. Scaphitesnæsen.

Fig. 2 A: Equatorial cross-section of a fruit. P: pericarp. em: embryo sack. N: nucellus. C: columella. ra: raphe. The raphe is seen along the lower side of nucellus. $-\times$ 6.5. GGU no. 9249.69 (thin section a). Loc. Scaphitesnæsen.

Fig. 2 B: Cross-section of the same specimen as fig. $2 \mathrm{~A}$, placed in proximal position to fig. $2 \mathrm{~A}$. The raphe is seen along the lower border of the nucellus. $\times$ 6.5. GGU no. 9249.69 (thin section b). Loc. Scaphitesnæsen. 

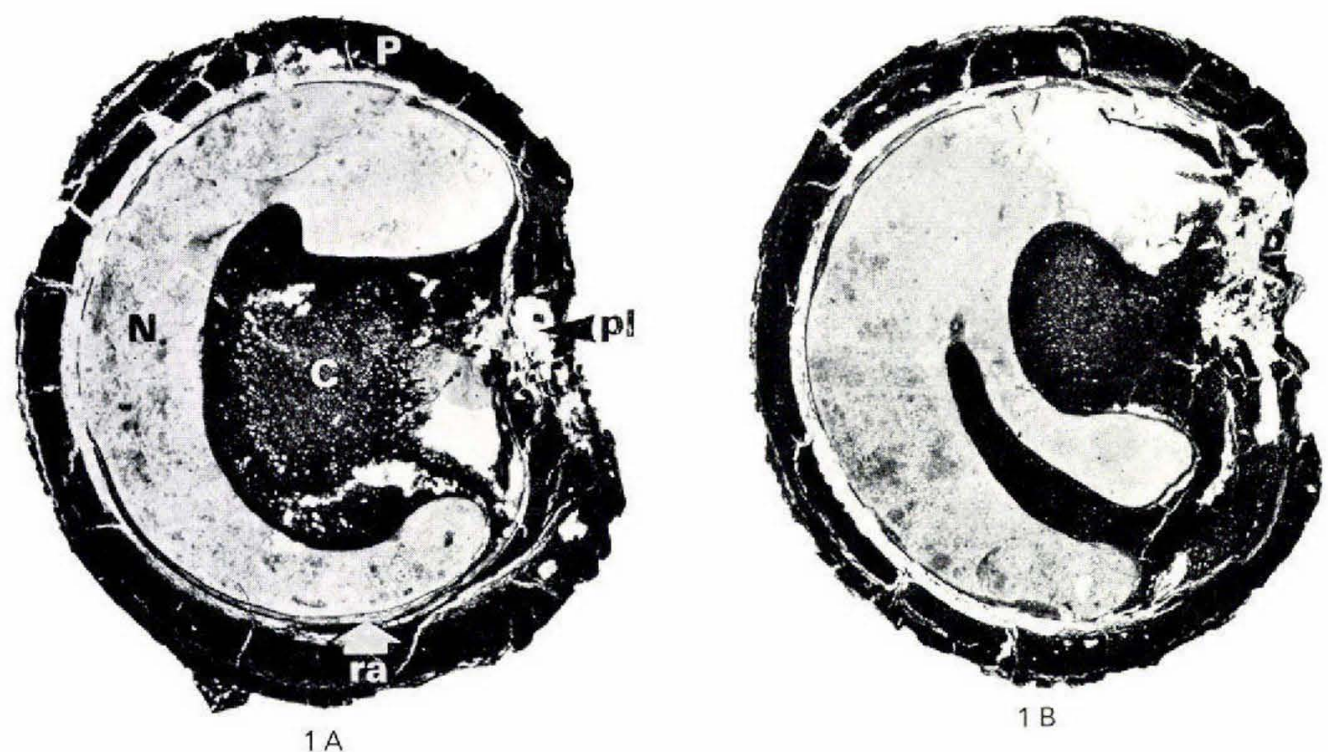

$1 \mathrm{~cm}$

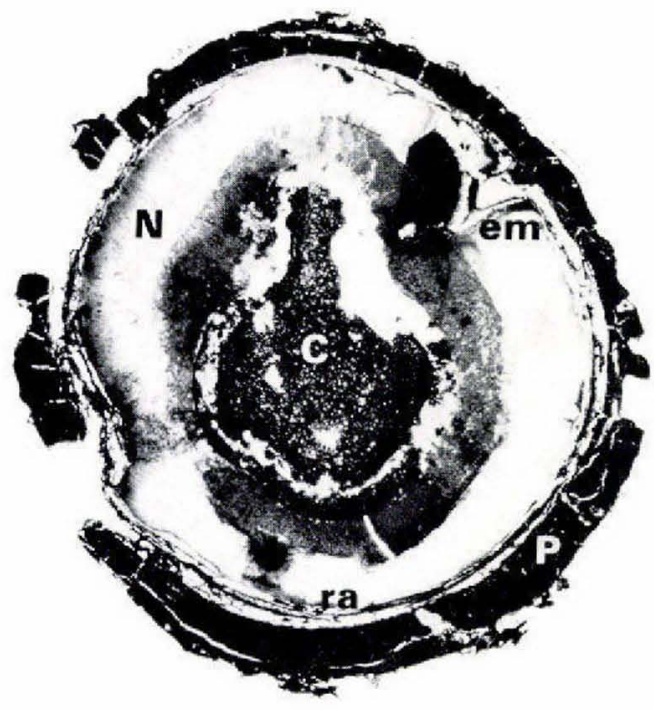

$2 \mathrm{~A}$

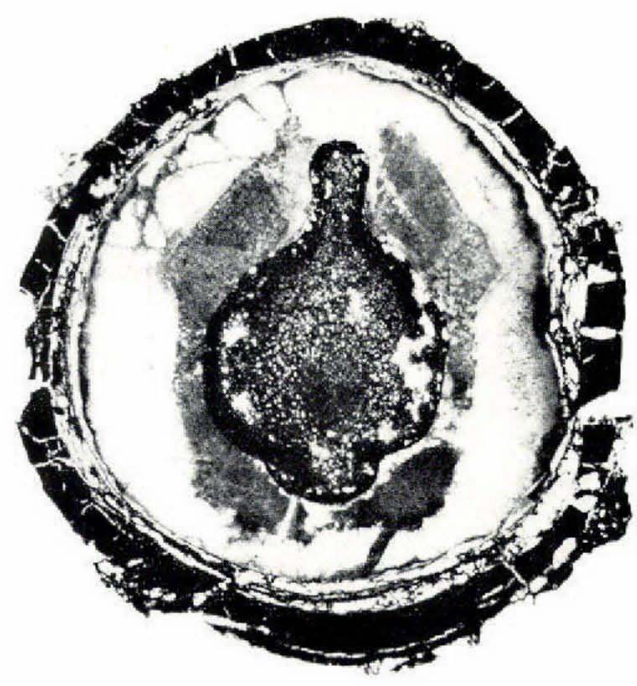

$2 \mathrm{~B}$ 


\section{Plate 3}

Coryphoides poulseni n.gen. et n.sp.

Fig. 1: Cross-section of the distal hemisphere of the same fruit as the section on pl. 2, fig. $2 \mathrm{~A}-\mathrm{B}$. P: pericarp. $\mathrm{N}$ : nucellus. cv: chalaza valve ('internal chalaza'). - × 6.5 GGU no. 9249.69 (thin section c). Loc. Scaphitesnæsen.

Fig. 2: Extreme lateral length-section parallel to the plane of symmetry. The same specimen as pl. 2, fig. 1 A-B. N : nucellus. P: pericarp. ra: raphe.$\times$ 6.5. GGU no. 9249.62 (thin section 3). Loc. Scaphitesnæsen.

Fig. 3: Basal cross-section of a seed with recrystallized nucellar structure. The tissues of the columella base are strongly disintegrated. $-\times 6.5$. GGU no. 8173.1 (thin section 1). Loc. Qaersutjægerdal: big section.

Fig. $4 \mathrm{~A}$ : Central length-section in the symmetry plane of a seed. The columella tissue has been partially dissolved and replaced by sand grains. $-\times 6.5$. GGU no. 9249.65 (thin section 1). Loc. Scaphitesnæsen.

Fig. 4 B: Lateral length-section parallel to the symmetry plane of the same specimen as fig. $4 \mathrm{~A}$. The columella has been strongly dissolved and replaced by calcite. To the lowermost right a papilla penetrates the remains of the pericarp (stylar base) (cf. pl. 5, fig. 2). The pericarp is preserved in the distal end where it contains a plug of disintegrated tissue (cf. pl. 5, fig. 3). (germinating pore?). To the left a special structure is seen (cv) which is at least partly the chalaza valve. $-\times 6.5$. GGU no. 9249.65 (thin section 2). Loc. Scaphitesnæsen. 


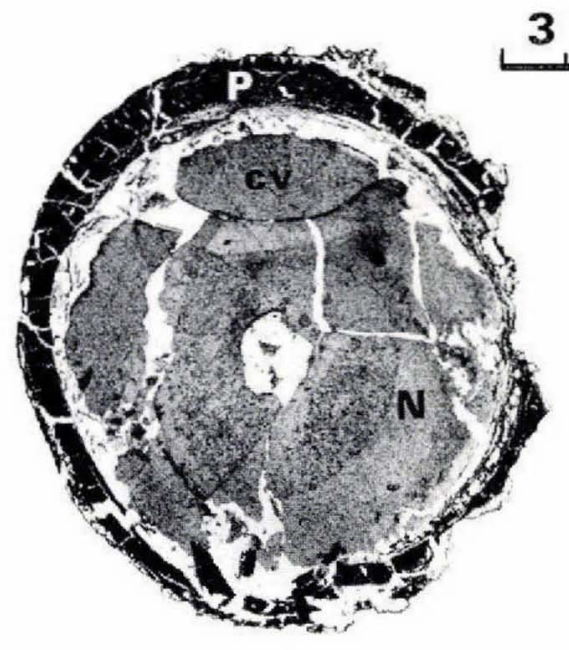

1
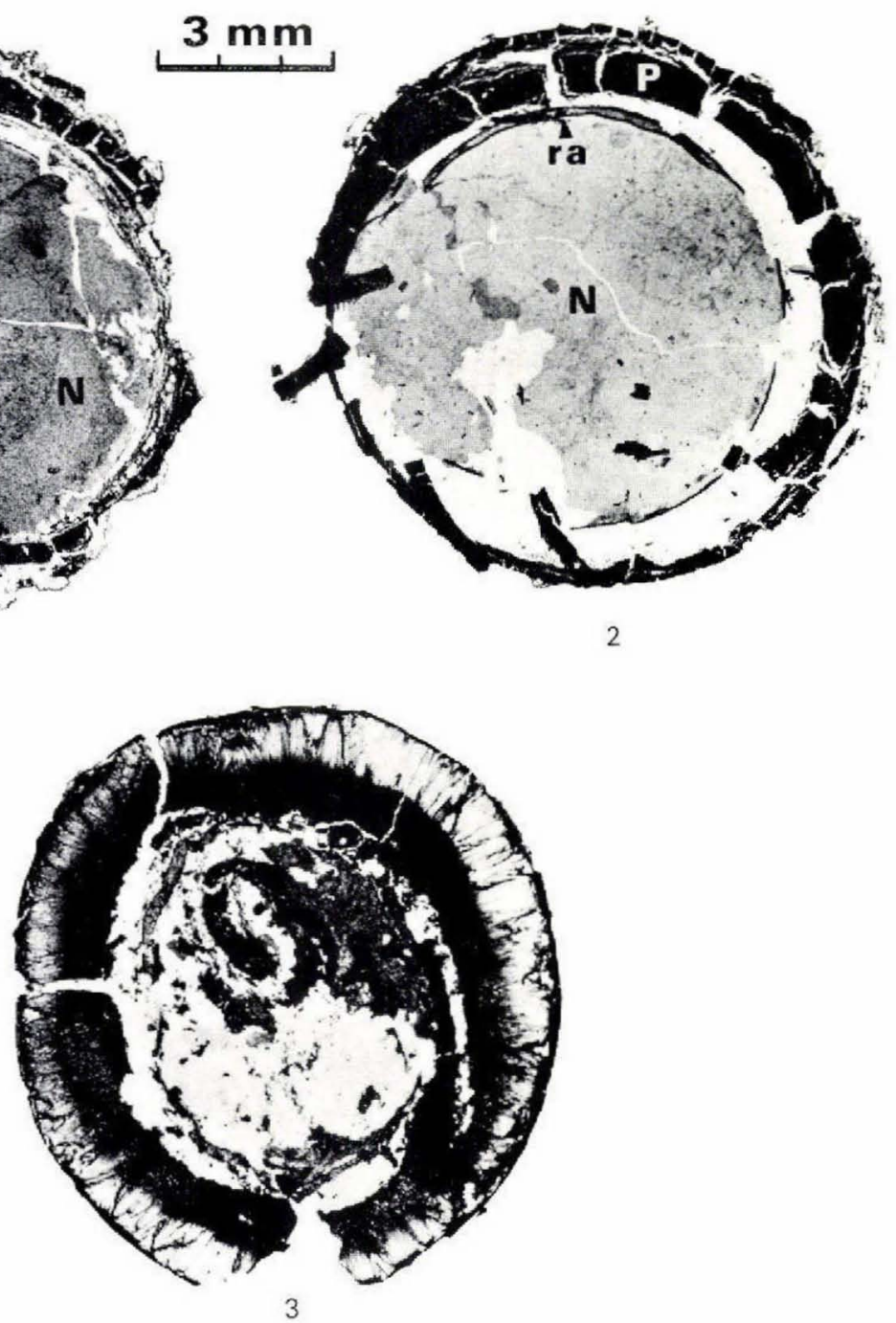

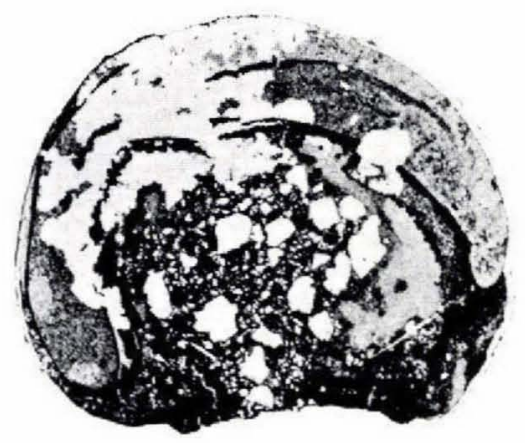

$4 \mathrm{~A}$

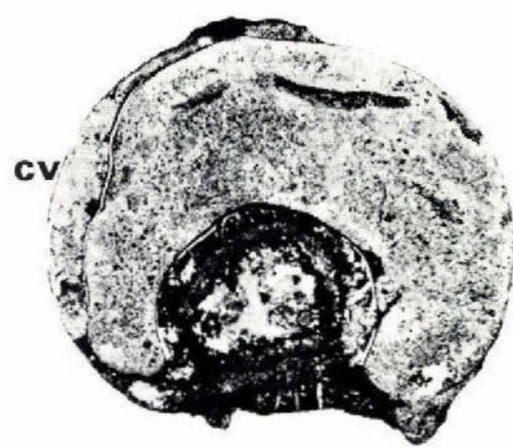

4 B 


\section{Plate 4}

Fig. 1: Coryphoides poulseni n.gen. et n.sp. Length-section in the symmetry plane of a fruit. The resistant tissues of the columella (C) and pericarp (P) are strongly incoaled, the calcite of the nucellar structure $(\mathrm{N})$ is recrystallized in spherical aggregates. ra: raphe. $-\times 6.5$. GGU no. 9249.67 (thin section 1). Loc. Scaphitesnæsen.

Fig. 2: Coryphoides poulseni n.gen. et $n$.sp. Length-section in the symmetry plane of a fruit. The resistant tissues of the columella and pericarp are strongly incoaled. The calcite of the interstices of the incoaled columella and of the nucellus structure is recrystallized. $-\times 6.5$. GGU no. 9249.66 (thin section 1). Loc. Scaphitesnæsen.

\section{$\mathrm{X}$-ray photographs}

Fig. 3: Coryphoides poulseni n.gen. et n.sp. Projection in a plane at right angles to the symmetry plane of a fruit, demonstrating the placental scar, the maximum width of the columella and the funiculus-raphe strand. $\times 2.5$. GGU no. 9249.64 .

Fig. 4: Undetermined fossil. Projection in a plane at right angles to the longest axis of an ovoid fossil fruit. The structure seems rather massive and undifferentiated. $-\times 2.5$. GGU no. 9249.8 .

Fig. 5: Coryphoides poulseni $\mathrm{n}$.gen. et $\mathbf{n}$. sp. Projection in a plane at right angles to the axis of a fruit. The placenta and the funiculus-raphe strand is seen. The chalaza valve is seen like a ghost oval cut by the raphe. - About $\times 2.5$. GGU no. 8179.2.

Fig. 6 A: Undetermined paIm-like fossil fruit. Projection in a plane at right angles to the plane of symmetry of the fruit. A columella is seen as a ghost black area. The fossil seems rather undifferentiated mineralogically, but resembles a coryphoid palm seed. - About $\times 2$. GGU no. 8172.1

Fig. $6 \mathrm{~B}$ : Undetermined palm-like fossil fruit. Projection in a plane parallel to the symmetry plane of the fruit of fig. $6 \mathrm{~A}$.

Fig. 7 A: Coryphoides poulseni n.gen. et n.sp. Projection in a plane parallel to the symmetry plane of an entire fruit (cf. pl. 1, fig. $6 \mathrm{~A}-\mathrm{B}$ ). The fruit has a thick, strongly incoaled pericarp entirely preserved. It seems that this coat prevents a detailed reproduction by X-ray. - About $\times 2$. GGU no. 9249.63. Loc. Scaphitesnæsen.

Fig. 7 B: Coryphoides poulseni n.gen. et n.sp. Projection in a plane at right angles to the axis of the entire fruit of pl. 1, fig. 6 A-B. (GGU no. 9249.63). The placenta and the raphe are seen. In accordance with the somewhat compressed fruit the X-ray photograph shows some deformation of the interior structure. - About $\times 2$.

Fig. 8 A: Coryphoicarpus globoides n.gen. et n.sp. Projection in a plane at right angles to the axis of the fruit of pl. 16, fig. $1 \mathrm{~A}-\mathrm{C}$. The photograph is very detailed and shows clearly the placenta (columella base) and the broad raphe strand. The former is distinctly smaller, the latter is stronger than the corresponding features in Coryphoides poulseni. - About $\times 2.5$. GGU no. 20166.

Fig. 8 B: Coryphoicarpus globoides n.gen. et n.sp. Projection in a plane parallel to the symmetry plane of the fruit of pl. 4 , fig. $8 \mathrm{~A}$ and pl. 16 , fig. $1 \mathrm{~A}-\mathrm{C}$. The columella has a narrow base (placental scar) and is saccate with a distinct, reversed pocket. - About $\times 2.5$. GGU no. 20166 .

The X-ray photographs of pl. 4 were produced by Mrs. J. Winther. 


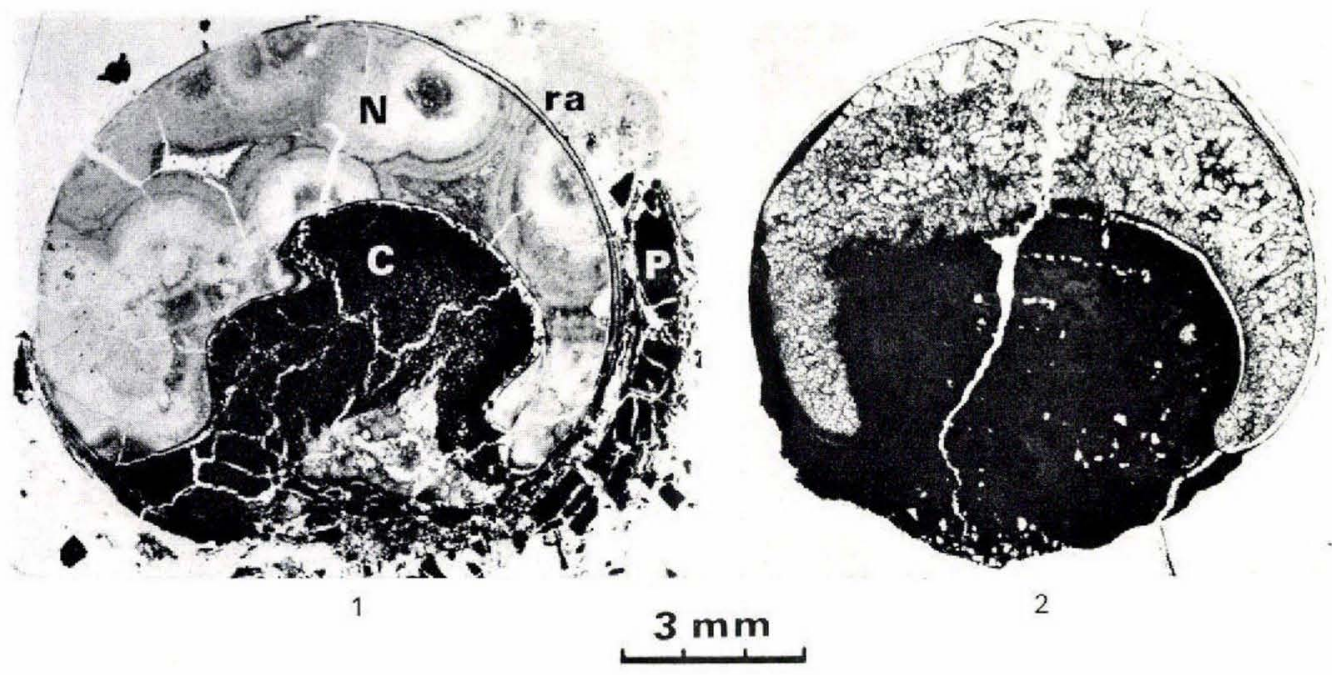

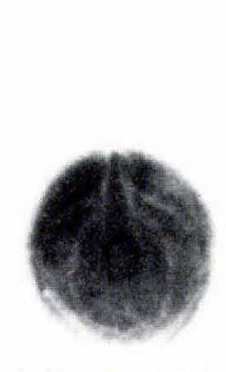

3

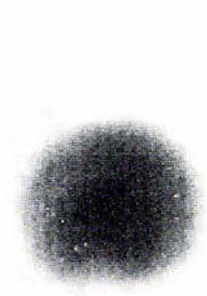

$6 \mathrm{~A}$

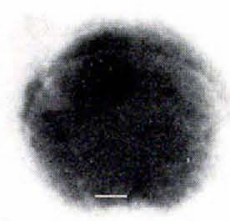

$7 \mathrm{~A}$

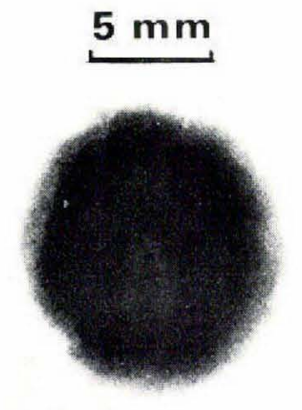

4

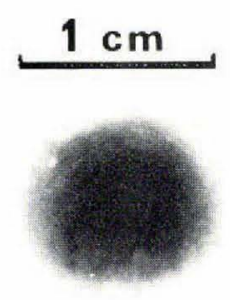

$6 \mathrm{~B}$

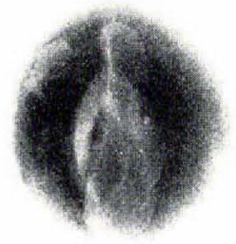

$7 \mathrm{~B}$

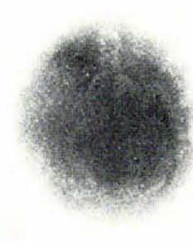

5

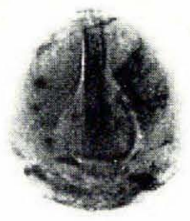

$8 \mathrm{~A}$

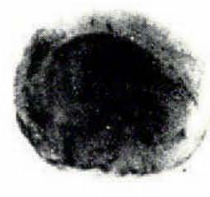

$8 B$ 


\section{Plate 5}

Coryphoides poulseni n. gen. et n.sp.

Fig. 1: Cross-section of the pericarp: ex: exocarp. mc: mesocarp. en: endocarp. ra: raphe. E: endosperm. $-\times 26$. Length-section in the plane of symmetry of GGU no. 9249.62 (thin section 1).

Fig. 2: Detail of the stylar region just outside the placental scar (pc) (opposite to the raphe). A projection ( $\mathrm{x}$ ) from the seed (S) (nucellus) penetrates the the pericarp (P). This may represent the basal structure of the flower or the stylus. ps: placental scar. Length-section parallel to the symmetry plane c. $1 \mathrm{~mm}$ from the latter. $-\times 35$. GGU no. 9249.65 (thin section 2).

Fig. 3: Detail of the region near the distal pole of the fruit: T: testa, perhaps fused with the inner pericarp. E: endosperm. The pericarp is interrupted by a plug of disintegrated tissue (z) (pag. 19). Fungal spores are crowded in this structure as well as in the pericarp (not visible at this magnification). The same thin section as pl. 5, fig. $2 .-\times 35$. GGU no. 9249.65 (thin section 2). 

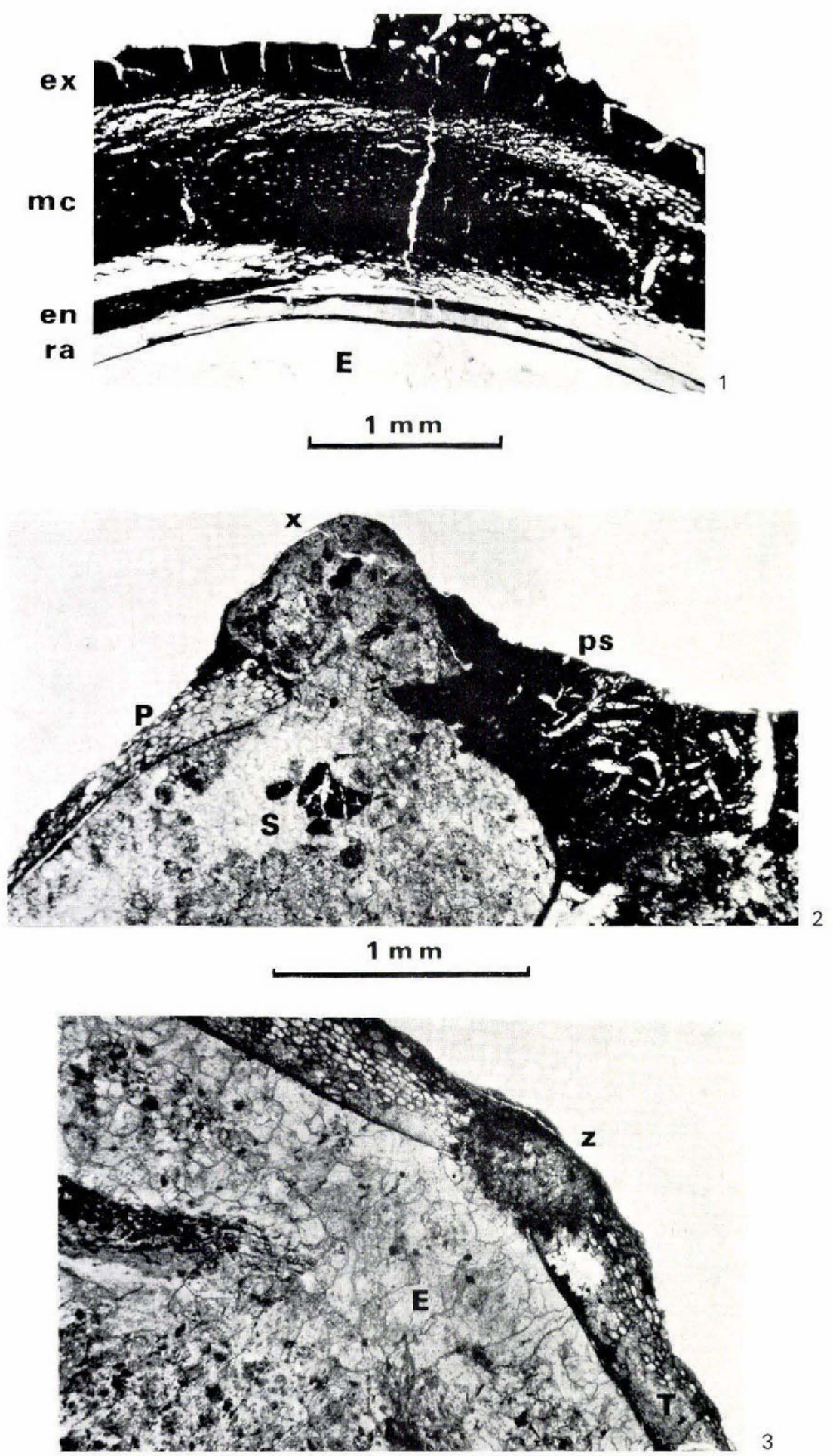

$1 \mathrm{~m} \mathrm{~m}$ 


\section{Plate 6}

Coryphoides poulseni n. gen. et n.sp.

Fig. 1: Detail of the placental region of the fruit. The lower border represents the abscission scar ('placental scar') (ps) of the fruit. P: pericarp. cs: conducting strand (disintegrated) passing through the pericarp. $\mathrm{F}$ : funiculus. $\mathrm{H}$ : hilum. E: endosperm of the seed. C: columella. $-\times 26$. Central lengthsection in the symmetry plane of GGU no. 9249.62 (thin section 1).

Fig. 2: Detail of pl. 6, fig. 1: The disintegrated funiculus with the spiral thickenings of the vessels in disorder. $-\times 312$. 

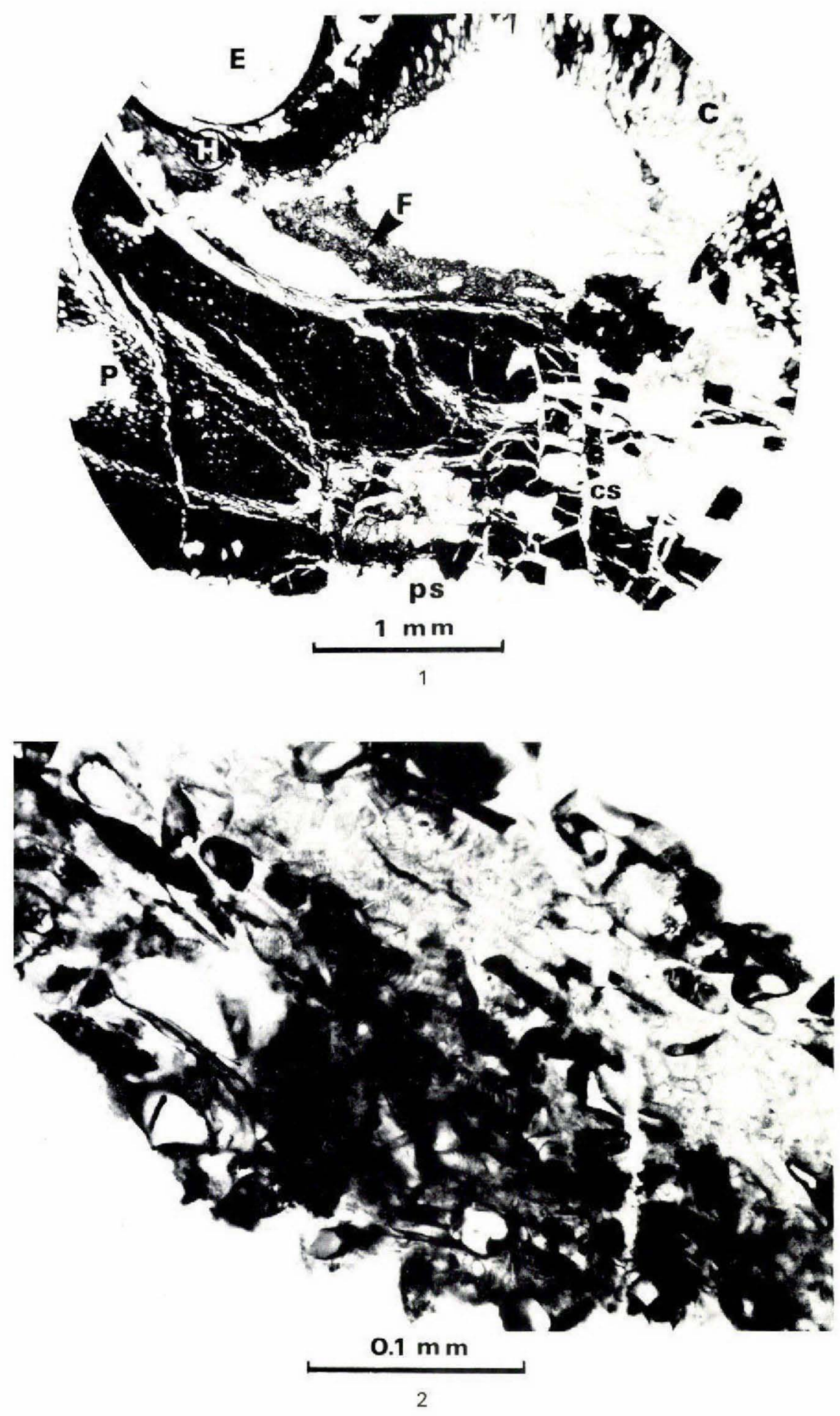


\section{Plate 7}

Coryphoides poulseni n.gen. et n.sp.

Fig. 1: The raphe (ra). The vessels (ve) are partially preserved. E: endosperm. $\times$ 125. GGU no. 9249.62 (thin section 2).

Fig. 2: The raphe in detail. The spiral-thickenings are partially preserved, somewhat contorted. $-\times 312$. GGU no. 9249.62 (thin section 1).

Fig. 3: The columella (C) region in central length-section in the symmetry plane of the fruit. The tissue has been dissolved and replaced by sand grains and calcite. pp: peripheral palisade (incoaled). ps: placental scar. $-\times 35$. GGU no. 8173.4. 


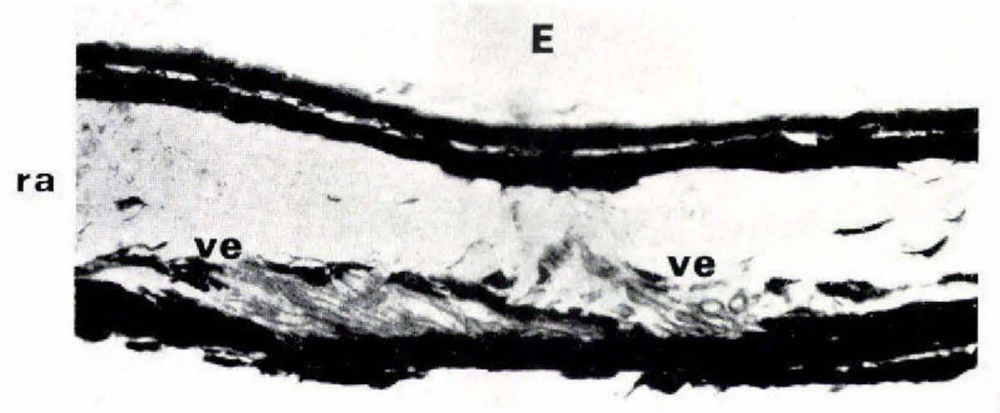

$0.1 \mathrm{~m} \mathrm{~m}$
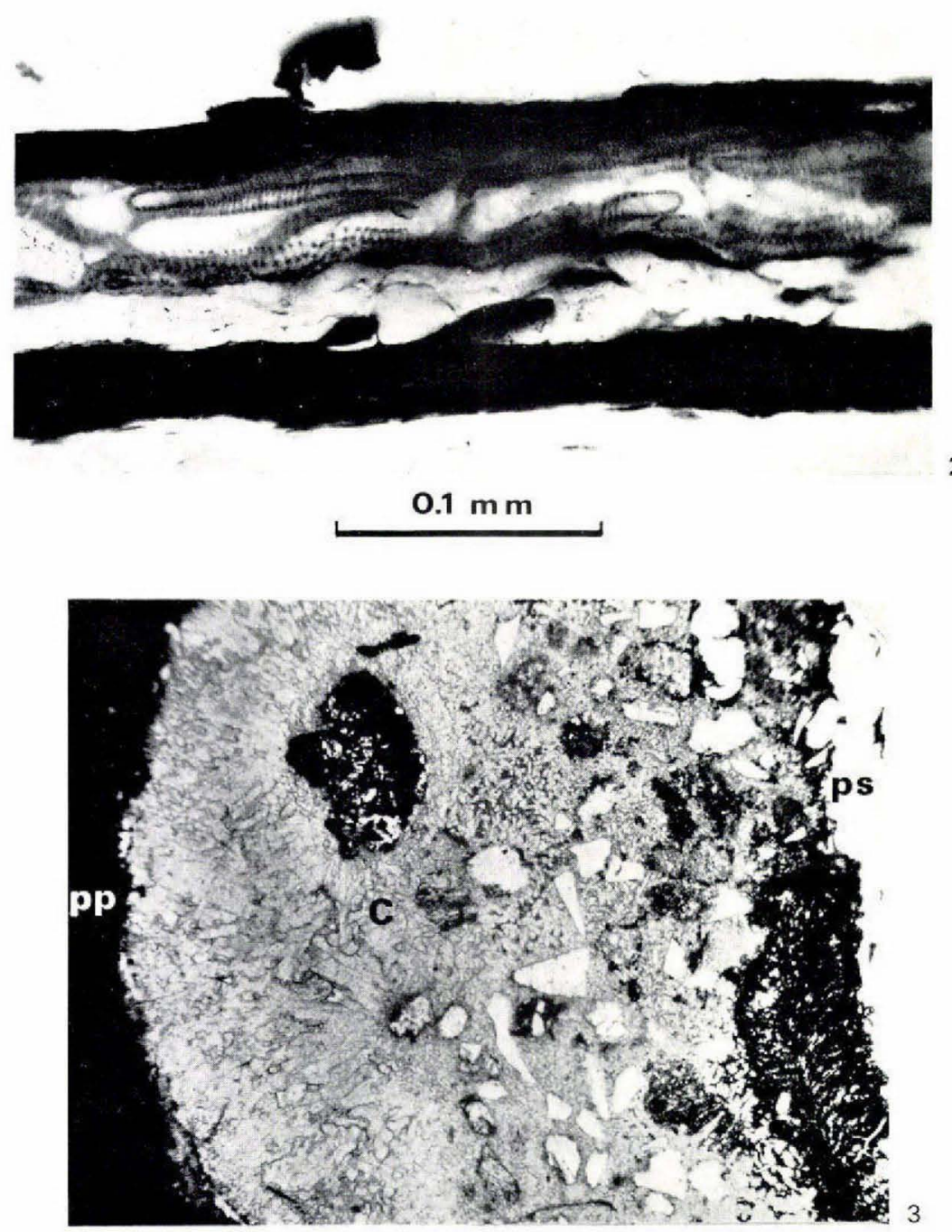

$1 \mathrm{~m} \mathrm{~m}$ 


\section{Plate 8}

Coryphoides poulseni $\mathrm{n}$.gen. et $\mathrm{n} . \mathrm{sp}$.

Fig. 1: The columella in central length-section in the symmetry plane. The tissue has been partially dissolved and replaced by sand grains and calcite. Along the inner periphery the palisade zone (pp) is preserved in a strongly incoaled condition. A peripheral zone of the ground tissue is preserved, even along the placental scar (to the left). P: pericarp in the region of placenta. S: seed. $-\times 35$. GGU no. 9249.65 (thin section 2 ).

Fig. 2: Detail of pl. 8, fig. 1. Tissue of the columella base (in the region of the placental scar). P: pericarp of the placenta region. The preserved tissue shows thick-walled cells (sclereids?). $-\times 125$. 

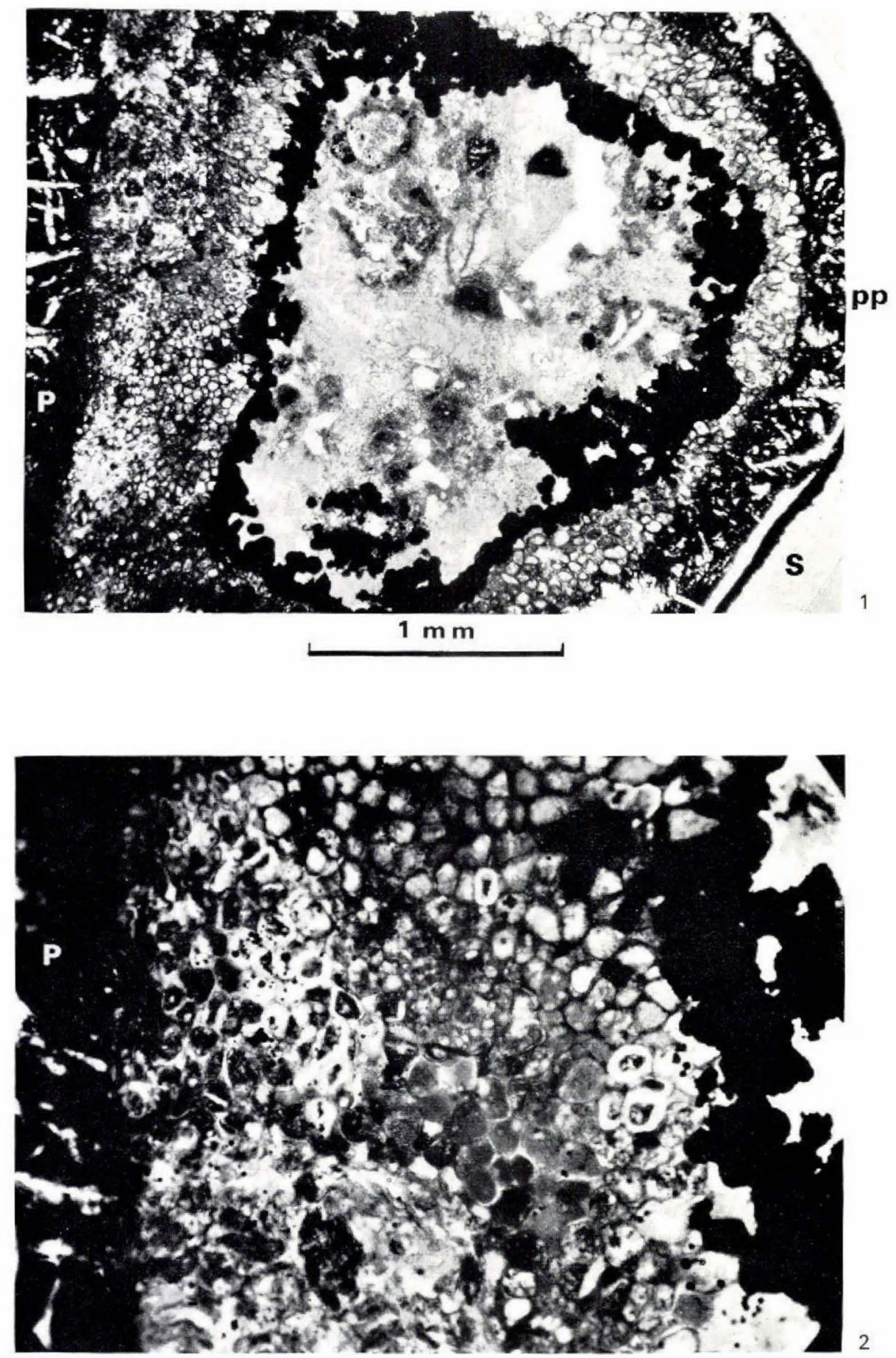


\section{Plate 9}

Coryphoides poulseni $\mathrm{n}$.gen. et $\mathrm{n} . \mathrm{sp}$.

Fig. 1: Tissues of the inner part of the columella (C) and the border zone towards the seed (to the right). The black border zone is a strongly incoaled palisade tissue (pp). E: endosperm. $-\times 44$. GGU no. 9249.62 (thin section 1).

Fig. 2: Detail of the same fossil specimen as pl. 9, fig. 1. E: endosperm. T: rudimentary testa. $p p$ : palisade. The palisade turns by a spiral into the ground tissue of the central part of the columella. - $\times 156$. GGU no. 9249.62 (thin section 2). 

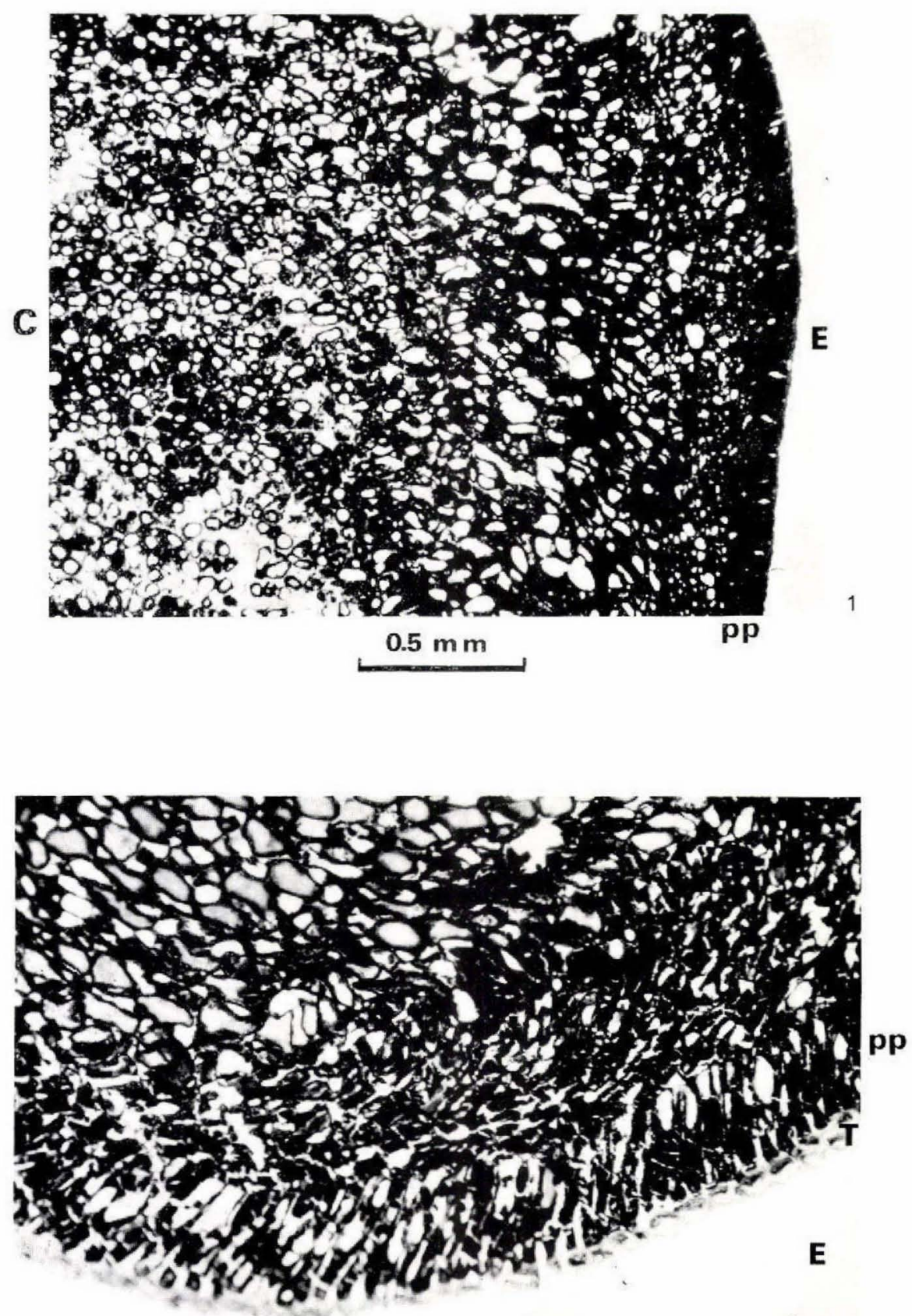


\section{Plate 10}

Coryphoides poulseni $\mathrm{n}$.gen. et n.sp.

Fig. 1: Detail of the distal region of the columella (C) with the palisade (pp) of its surface towards the seed in a length-section parallel to the plane of symmetry of the fruit. The palisade is strongly incoaled. The testa (T) in crosssection, one cell-layer thick. E: endosperm. $-\times 312$. GGU no. 9249.62 (thin section 2).

Fig. 2: The testa ( $T$ ) in cross-section with adhering incoaled remnants of the endocarp (en). The testa is one cell-layer thick. Below, the endosperm (E) is seen with ghost outlines of the cells. $-\times 156$. GGU no. 9249.62 (thin section 2).

Fig. 3: Tangential section through the layers of palisade tissue of the columella $(\mathrm{pp})$, the testal layer $(\mathrm{T})$ and the endosperm $(\mathrm{E}) .-\times 156$. GGU no. 9249.62 (thin section 2). 

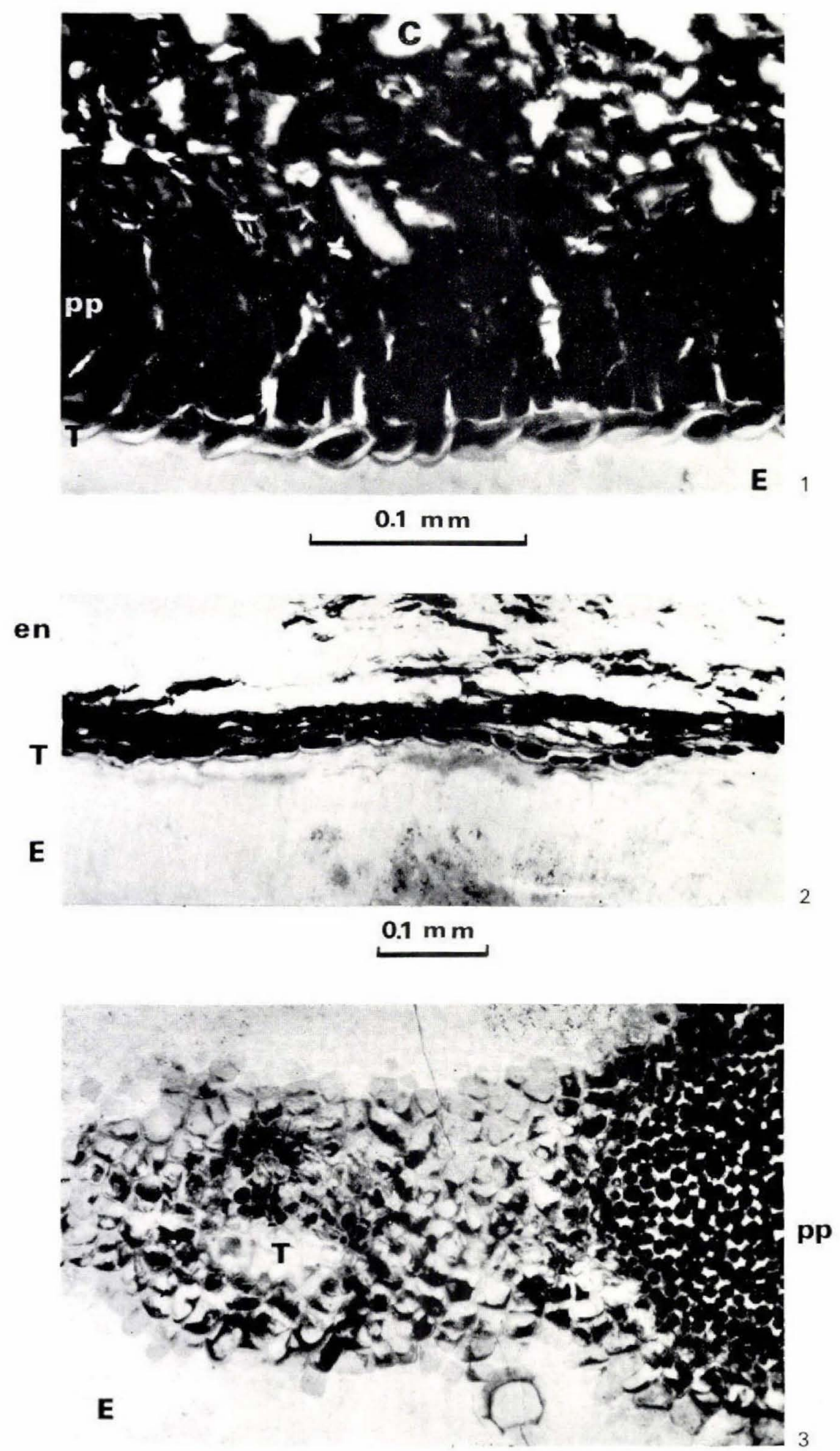

$0.1 \mathrm{~m} \mathrm{~m}$ 


\section{Plate 11}

Coryphoides poulseni n. gen. et n.sp.

Fig. 1: Nearly tangential (oblique) section through the testa showing the polygonal testal cells (T). C: columella. E: endosperm. $-\times 156$. GGU no. 9249.62 (thin section 2).

Fig. 2: Periphery of the seed with the rudimentary testa (T) (badly preserved) with adhering incoaled remnants. The rectangular endosperm cells are seen as ghost outlines just below testa. $\mathrm{E}$ : endosperm. en: endocarp. $\times 156$. GGU no. 9249.62 (thin section 1).

Fig. 3: Periphery of the seed with adhering raphe (ra) (to the left). The rectangular endosperm cells are seen as indistinct structures. E: endosperm. T: testal tissues. $-\times 156$. GGU no. 9249.62 (thin section 1). 

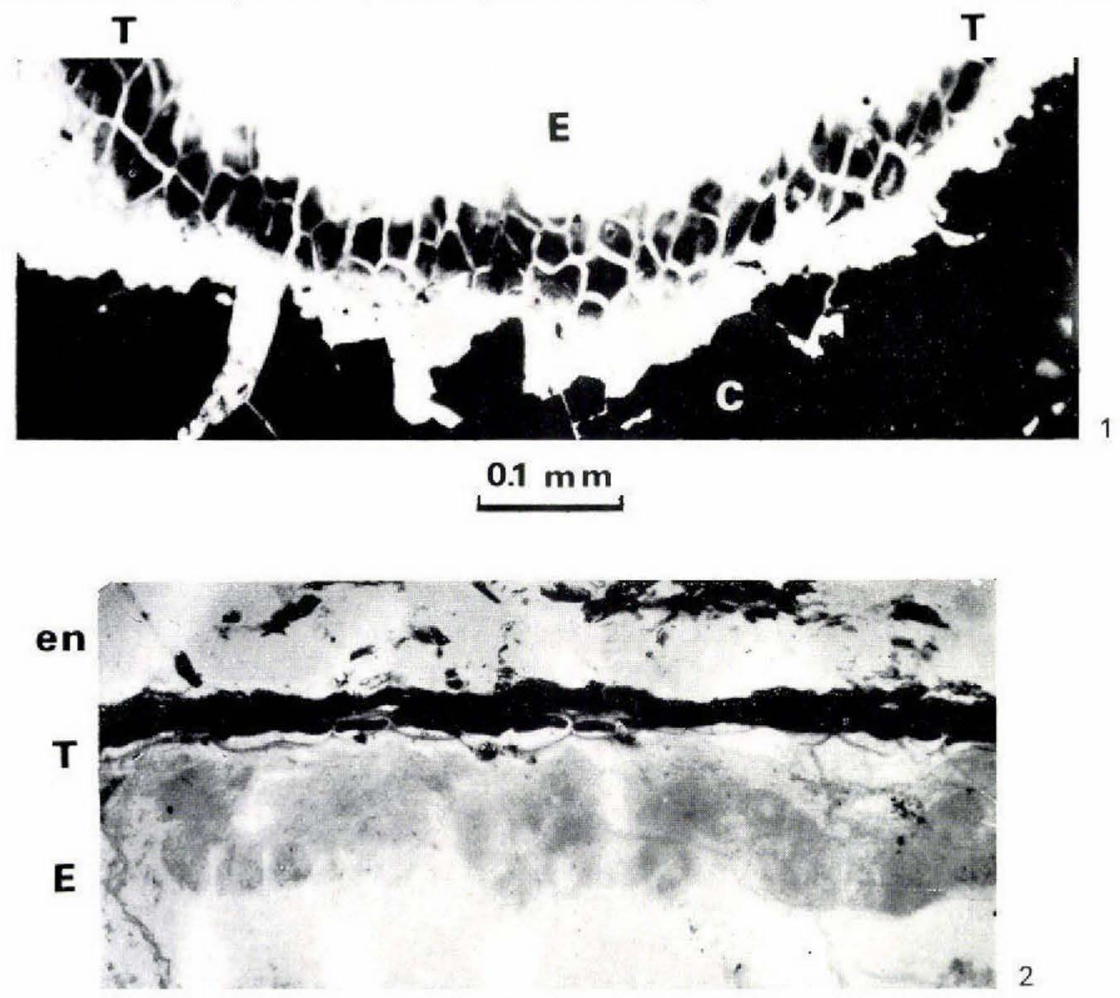

$0.1 \mathrm{~mm}$
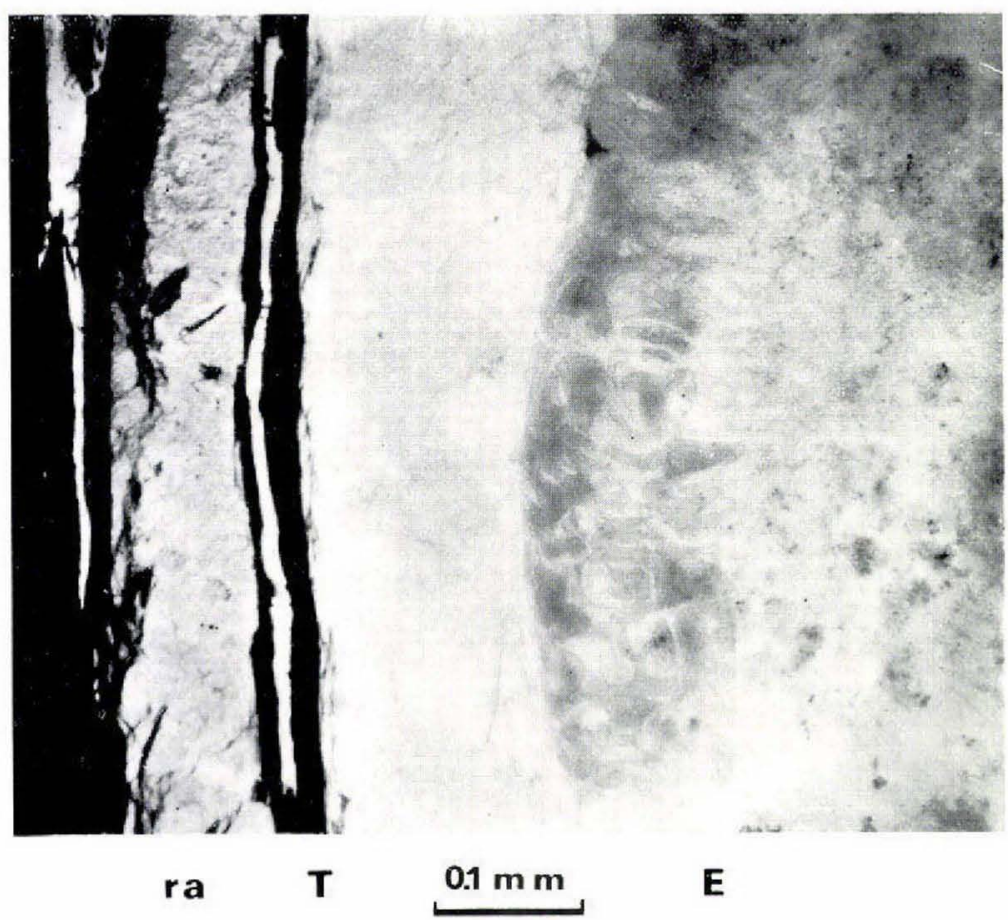


\section{Plate 12}

Coryphoides poulseni n.gen. et n.sp.

Fig. 1: Detail of equatorial cross-section of fruit (cf. pl. 2, fig. 2 A). The embryo sack is seen projecting into the endosperm from the surface of the seed. E: endosperm, em: embryo sack. P: pericarp. $-\times 35$. GGU no. 9249.69 (cross-section no. a).

Fig. 2: Detail of terminal part of the seed in a lateral length-section of a fruit parallel to the plane of symmetry. E: endosperm with a pigment which may, at least partly, consist of remains of the original cellular structure. $\mathrm{cv}$ : chalaza valve. $-\times 35$. GGU no. 9249.65 (thin section no. 2). 


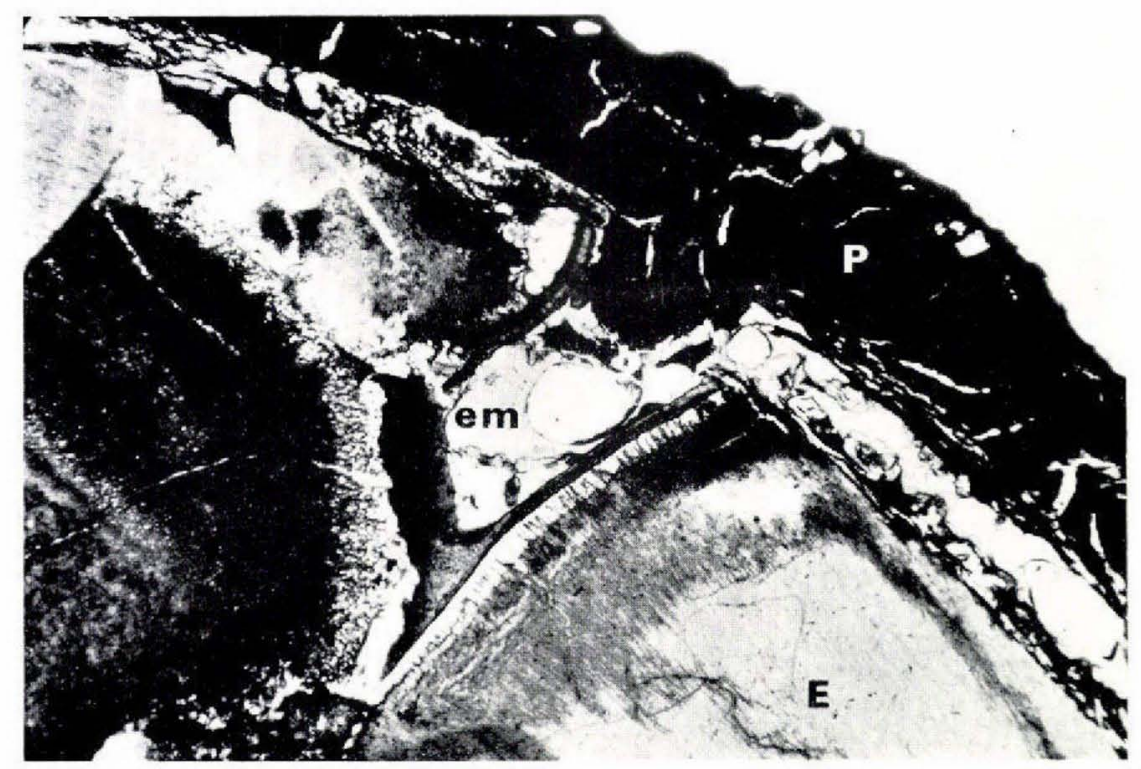

$1 \mathrm{~m} \mathrm{~m}$

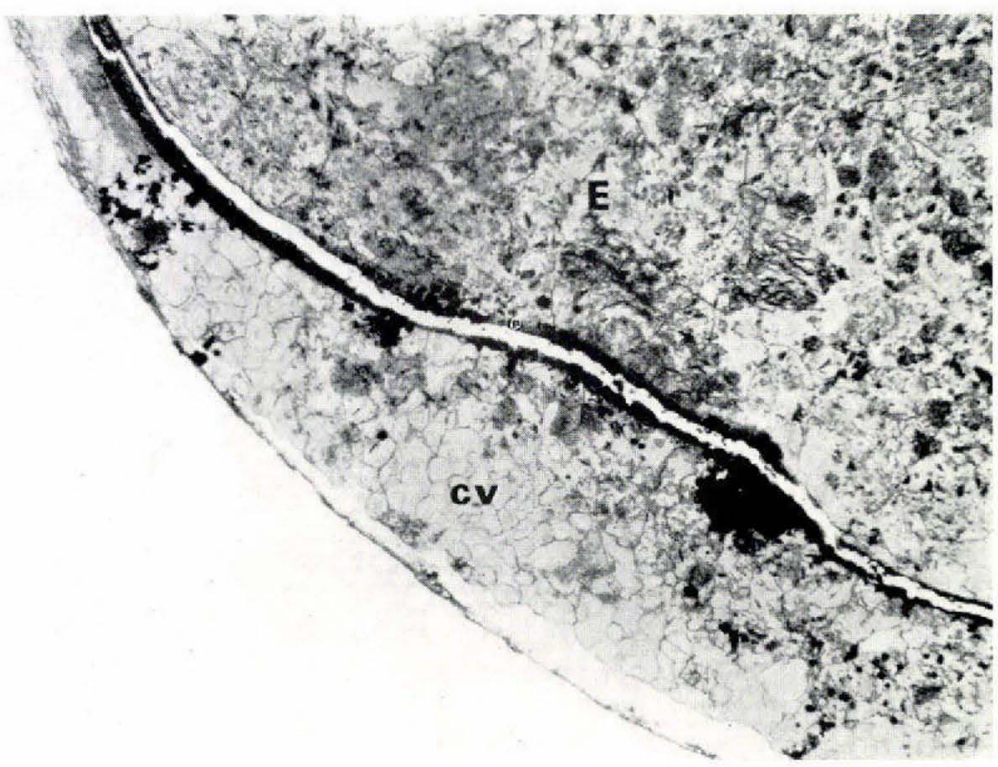

$1 \mathrm{~m} \mathrm{~m}$ 


\section{Plate 13}

Coryphoides poulseni $\mathbf{n}$. gen. et $\mathbf{n} . \mathbf{s p}$.

Fig. 1: Disintegrated cellular tissue of the columella with fungal spores, a teleuto spore and branched hyphae. $-\times 250$. GGU no. 9249.65 (thin section 2)

Fig. $2 \mathrm{~A}$ : Disintegrated cellular tissue of the pericarp with monoserial and biserial teleutospores. $-\times$ 187.5. GGU no. 9249.62 (thin section 2).

Fig. 2 B: Teleutospore in detail. Detail of pl. 13, fig. 2 A. $-\times 500$.

\section{Erythea sp.}

Fig. 3 A-B: Recent fruits. An entire seed (3 A) and a seed cut along the plane of symmetry ( $3 \mathrm{~B}$ ). C: columella. E: endosperm. em: embryo. ra: raphe. $\times$ 1. Bot. Garden. Univ. of California, Berkeley. 

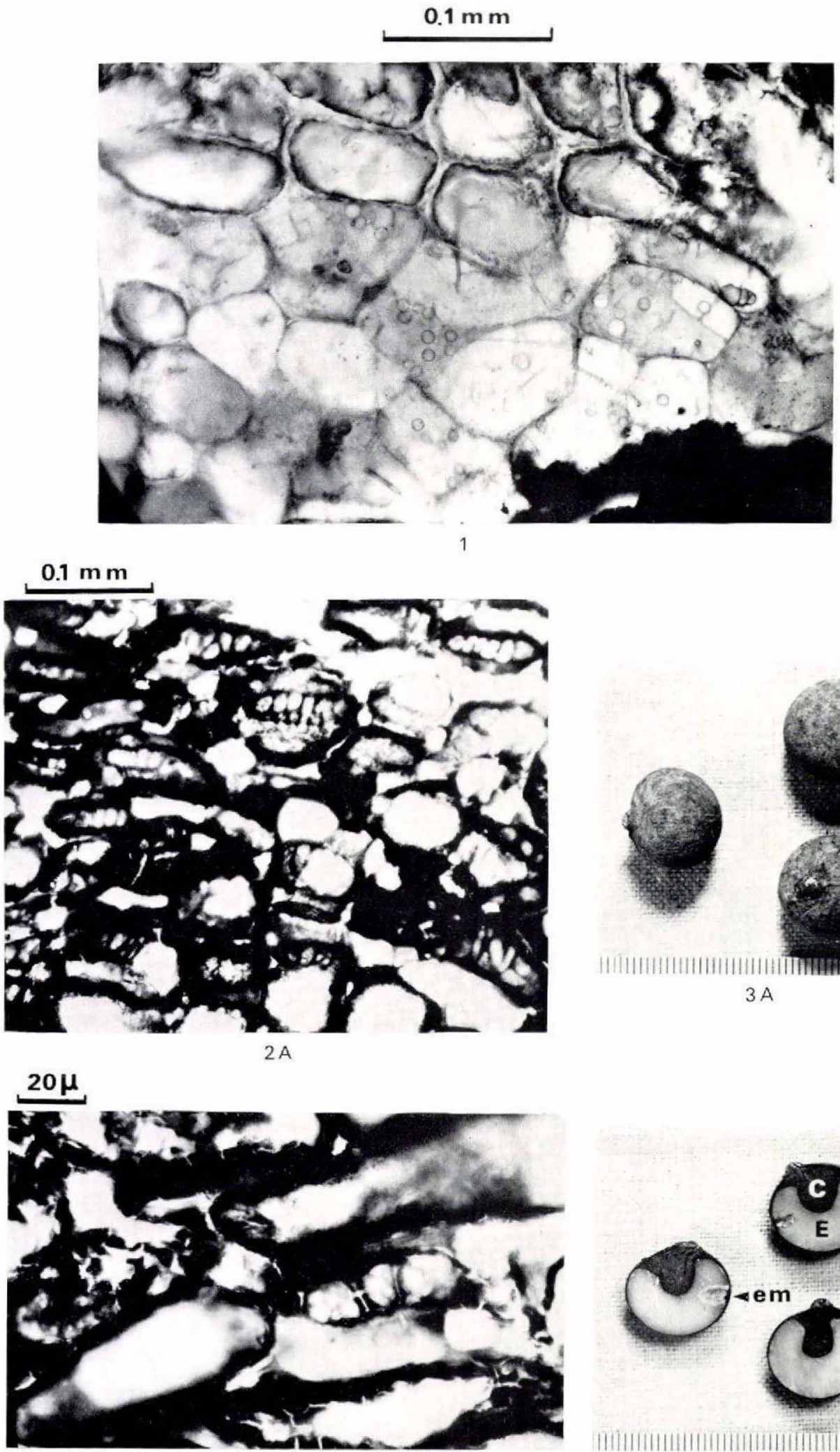

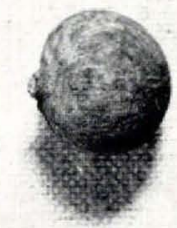

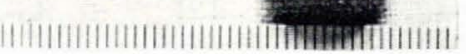

$3 \mathrm{~A}$
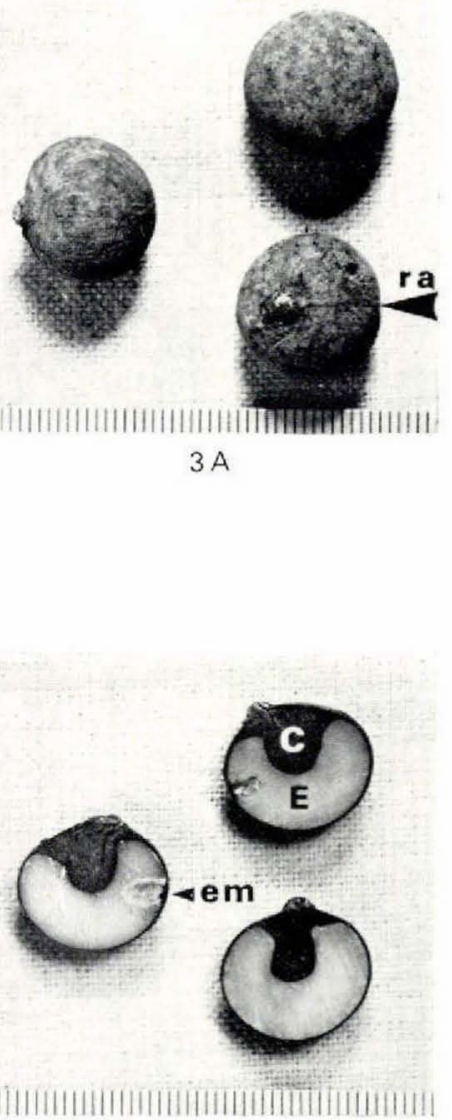

$3 \mathrm{~B}$ 


\section{Plate 14}

Fruits of recent coryphoid palms.

Fig. 1: Livistona rotundifolia. A seed in length-section along the symmetry plane, a pericarp and an entire fruit. - About $\times 1$.

Fig. 2: Livistona altissima. A seed biparted along the symmetry plane, and the pericarp. - About $\times$ 1. (Kew Gardens Herb.).

Fig. 3: Corypha? A seed in length-section. - About $\times 1$. Marseille (Kew Gardens Herb.).

Fig. 4: Livistona conchichinensis. A fruit partly opened and seeds cut along the plane of symmetry. - About $\times 1$. Dominica (Kew Gardens Herb.).

Fig. 5 A-B. Livistona australis. An entire seed and a seed cut along the plane of symmetry. (Kew Gardens Herb.).

Fig. 6: Thrinax keyensis. A fruit, an entire seed and a seed cut along the plane of symmetry. $-\times 2$. (Kew Gardens Herb.).

Fig. 7: Central and left row: Thrinax floridana. Left row: a seed cut along the plane of symmetry. Central row: a fruit and a pericarp. Right row: Brahea moorei, a seed in length-section. Florida. Derivation: The Fairchild Tropical Garden, Miami. $-\times 2$.

Fig. 8: Sabal glabra. Fruit, partly opened, the seed can be seen. $-\times 2.5$.

Fig. 9: Sabal glabra. Seeds in length-section, the seed of the left row is cut along the symmetry plane. $-\times 2.5$. 


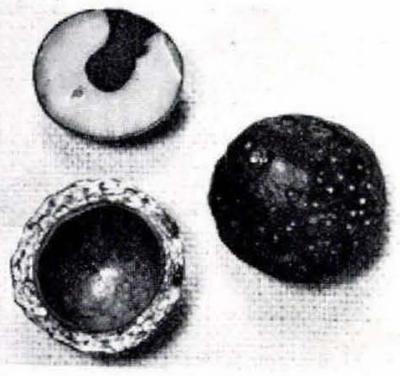

1

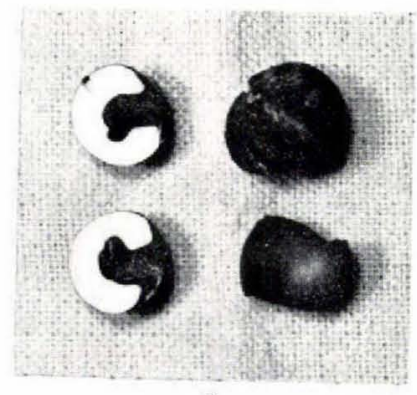

2

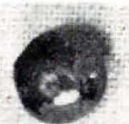

(3) (3)

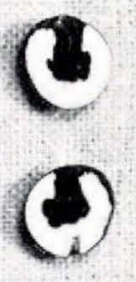

4

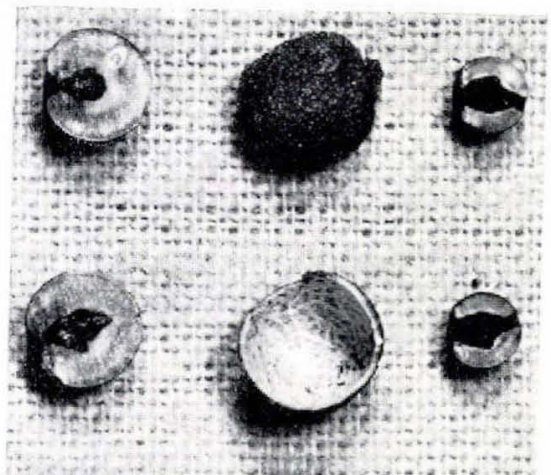

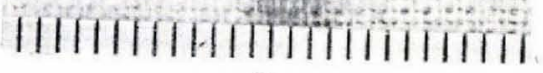

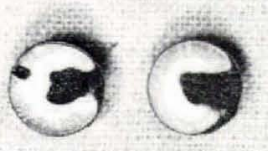

$5 \mathrm{~A}$

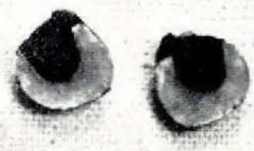

3

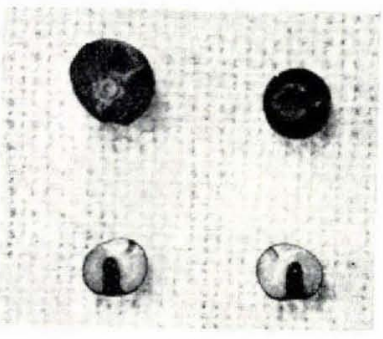

6

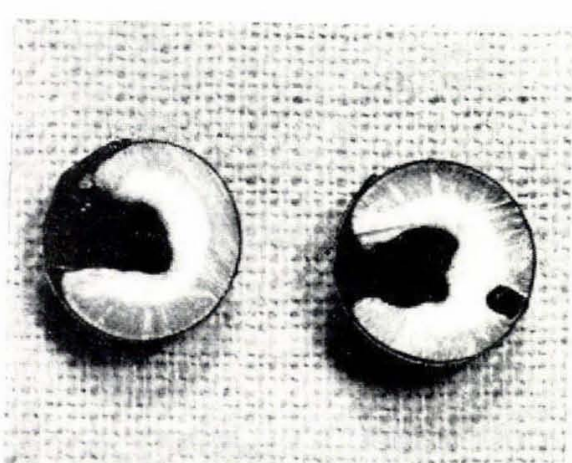

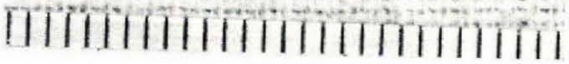

5 B

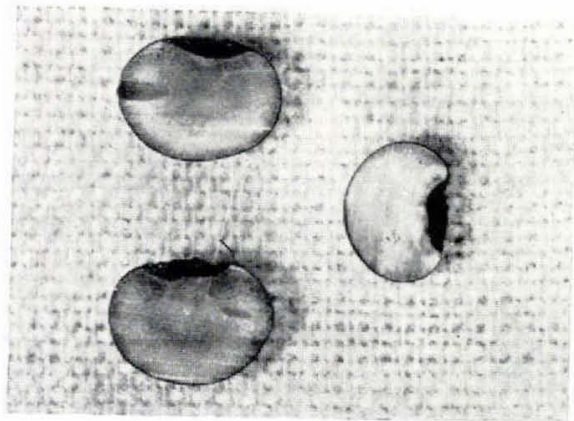




\section{Plate 15}

Erythea sp.: Thin sections of the seed.

Fig. 1: Length-section. C: columella with funicular strand. E: endosperm. F: funicular strand. T: functional testa. $-\times 5$.

Fig. 2: Equatorial cross-section. C: columella. E: endosperm surrounded by $\mathrm{T}$ : combined testa and remains of the inner pericarp (functional testa). Derivation: Bot. Garden, Univ. of California, Berkeley. $-\times 5$. 

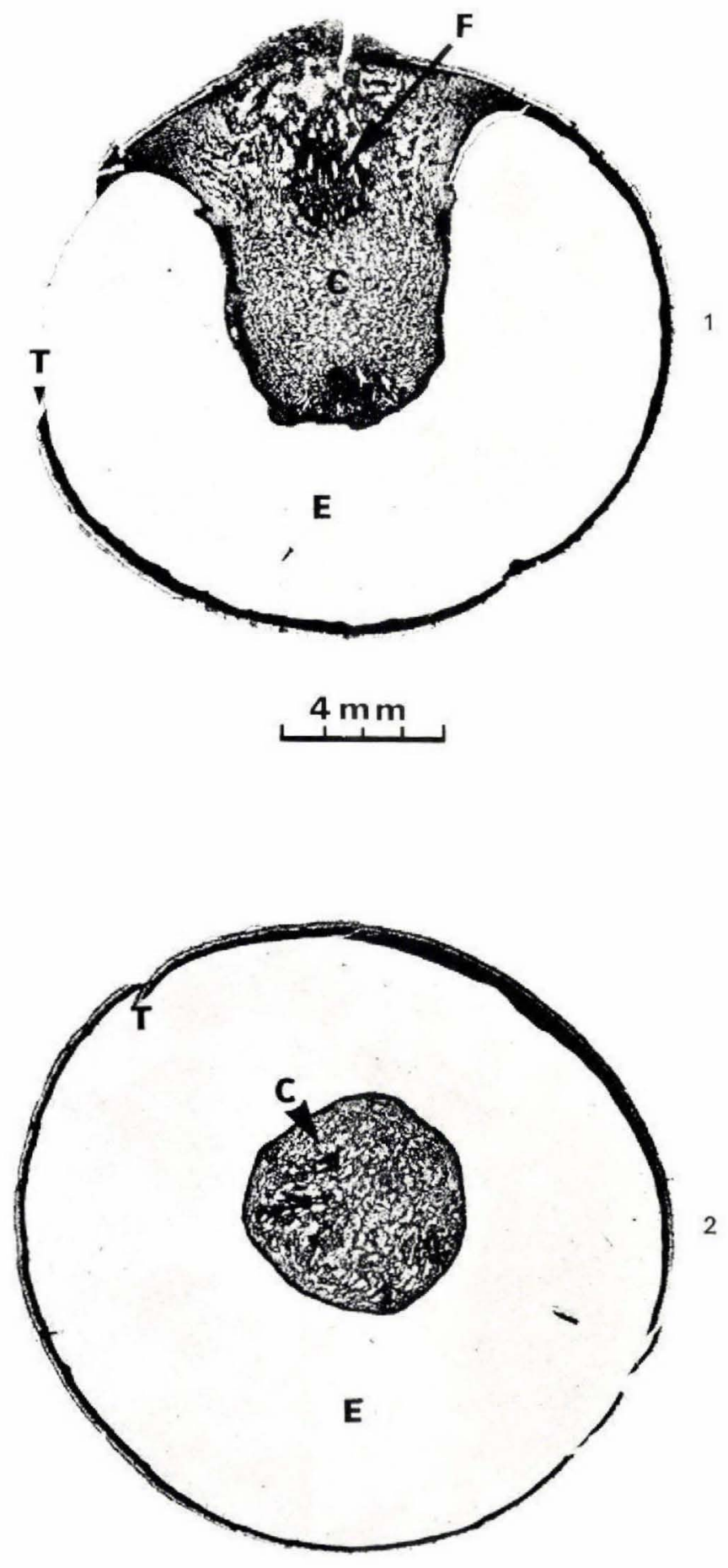


\section{Plate 16}

Coryphoicarpus globoides $\mathrm{n}$. gen. et $\mathrm{n}$. sp.

Fig. 1 A: The raphean end of the fruit. The placental scar (ps) is turned downwards. - About $\times$ 4.5. GGU no. 20166. Loc. Danienkløft, Tunorssuaq.

Fig. 1 B: The placental (proximal) end of the fruit. The placental scar and the raphe (ra) are seen. (The same specimen as pl. 16, fig. $1 \mathrm{~A}$ ). - About $\times \mathbf{4 . 5}$.

Fig. $1 \mathrm{C}$ : The same specimen as pl. 16 , fig. $1 \mathrm{~A}-\mathrm{B}$ in oblique view. cv?: chalaza valve? ps: placental scar. ra: raphe. - About $\times 4.5$.

\section{Palmospermum excavatum Reid \& Chander.}

J. Sommer photo.

Fig. 2 A-B: X-ray photographs. A: projection in a plane at right angles to the symmetry plane ('raphe plane'). The columella is indistinct and could not be distinguished on the $\mathrm{X}$-ray photograph alone. The raphe is visible. B : projection in a plane at right angles to the axis of the fruit. The extension of the columella is distinct. The raphe and the opposed columella ridge are seen in the symmetry plane. $-\mathrm{A}: \times 1.5 . \mathrm{B}: \times 3$. British $\mathrm{Mu}-$ seum, Natural History, type specimen no. 22023.

Mrs. J. Winter photo.

Fig. 3 A: Fruit seen from the proximal end. The placental scar is slit-like ('ventral depression') (vd), the columella is partly removed by weathering. E: endosperm. P: combined pericarp-testa. em: embryo. The same specimen as pl. 16, fig. 2 A-B. - About $\times 4$. British Museum, Natural History, type specimen no. 22023 (cf. Reid \& Chander (1933) pl. 1, fig. 25-26).

Fig. 3 B-D: The same specimen as pl. 16, fig. $3 \mathrm{~A} .-\times 3$.

Fig. 3 B: Seen from the end opposite to the raphe. em: embryo. E: endosperm. $\mathrm{P}$ : pericarp and testa. $\mathrm{vd}$ : 'ventral depression' (placental scar).

Fig. 3 C: Lateral oblique view. em: embryo. ic: 'internal chalaza' (chalaza valve).

Fig. 3 D: Oblique view from the end of the raphe with the distinct 'internal chalaza' (chalaza valve) (ic).

J. Sonmer photo. 


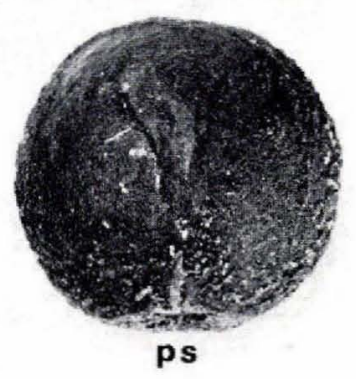

$1 \mathrm{~A}$

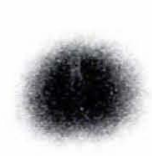

2A

$2 \mathrm{~B}$

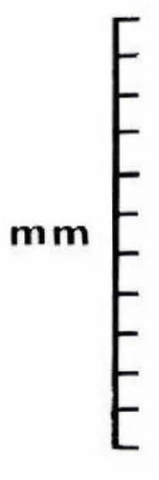

$3 \mathrm{~A}$
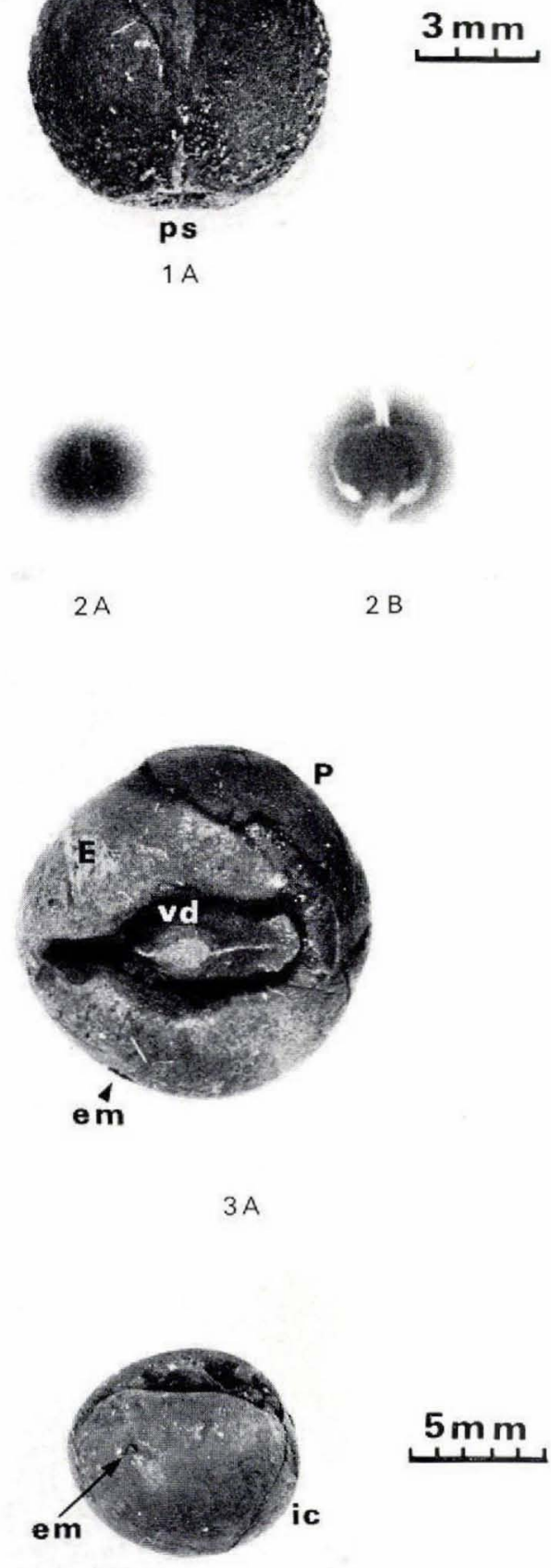

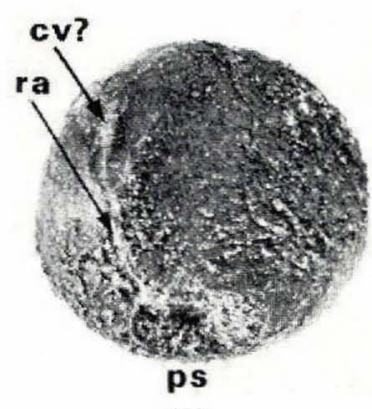

$1 \mathrm{C}$

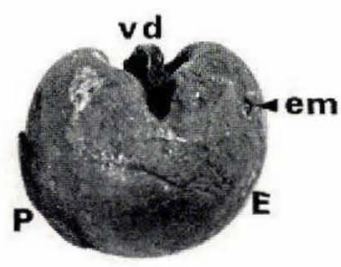

$3 \mathrm{~B}$

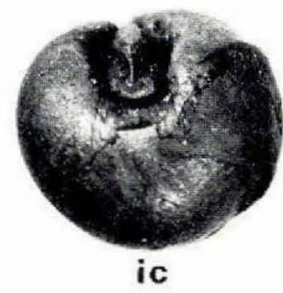

3D 


\section{Plate 17}

Fig. 1: Exflabellaria groenlandica (Нев) Lamotте. Type specimen of Flabellaria groenlandica $\mathrm{HeER}_{\mathrm{e}}=$ Exflabellaria groenlandica (НеeR) LAмотте. Fragment of fan-shaped leaf split into segments. $-\times 1$. Mineralogical Museum, University of Copenhagen. Original no. 6264. Loc. Atanikerdluk (Quikavsak Member).

J. Sommer photo.

Fig. 2: Coryphoides poulseni n.gen. et $n$.sp. Seed in oblique view from the raphe end, with chalaza valve (cv), remnant of the pericarp of the placental region $(\mathrm{P})$, and the surface of the endosperm structure $(\mathrm{E})$ preserved in transparent calcite. $-\times 5$. GGU no. 8179.2 . 


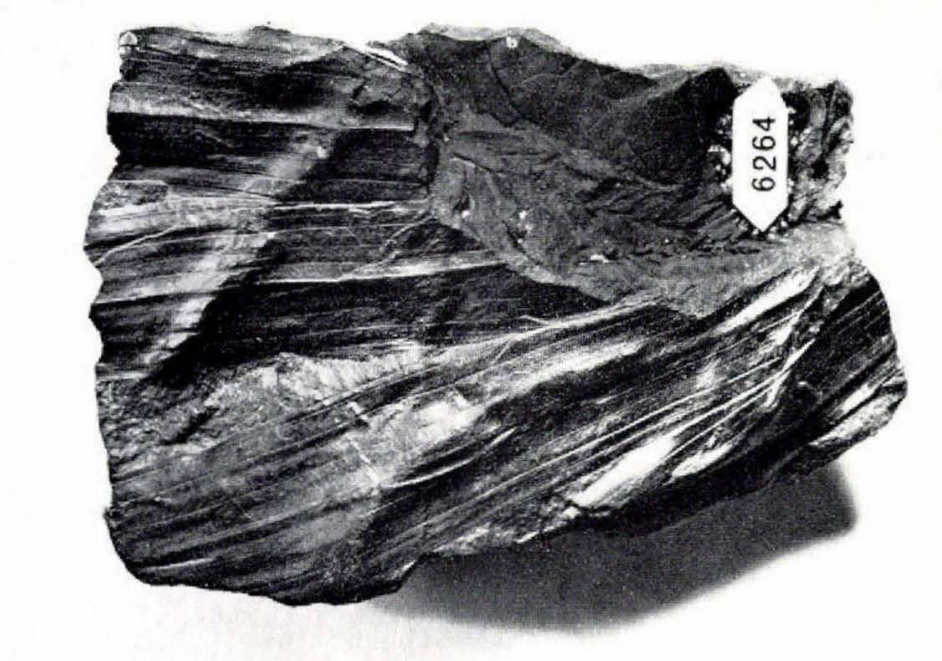

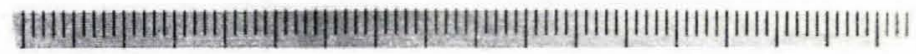

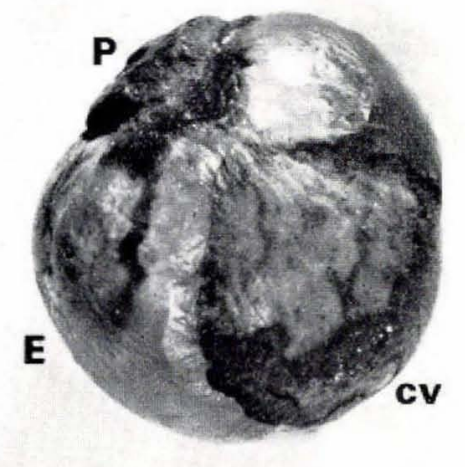

\section{$4 \mathrm{~m} \mathrm{~m}$}




\section{Plate 18}

Coryphoicarpus globoides n.gen. et n.sp.

Three stereo pairs of $\mathrm{X}$-ray photographs representing three sections at right angles to each other. $-\times 3$. GGU no. 20166 .

Fig. 1: Length projection parallel to the plane of symmetry. The extensive columella is clearly recorded with its 'reversed pocket'. The embryo (em) is in the centre of the image. The funiculus (F) makes a loop into the base of the columella and appears again at the surface at the hilum $(\mathrm{H})$ at the border of the placental scar. See textfig. $10 \mathrm{~A}$ for additional information.

Fig. 2: Length projection at right angles to the plane of the symmetry. The vertical, linear structure in the plane of symmetry is the raphe (ra) which ends in the oval chalaza (white). The columella appears to be a rather complicated structure. To the left of the raphe details of the 'reversed pocket' are visible. The embryo (em) is seen stretching into the endosperm struture from the surface. See textfig. $10 \mathrm{~B}$ for additional information.

Fig. 3: Cross-projection (i.e. parallel to the equatorial plane). The central cordate structure is the image of the placental scar. The funiculus with the 'loop' into the columellar base is visible, and continues from the hilum $(\mathrm{H})$ into the raphe (ra). The ghost discoid structure of the chalaza can be discerned, but is partly covered by the raphe. The embryo (em) is faintly recorded.

J. Sommer photo.

The stereo pairs are adjusted to $6.5 \mathrm{~cm}$ ocular distance of the stereoscope, and can be studied with a simple pocket stereoscope. 

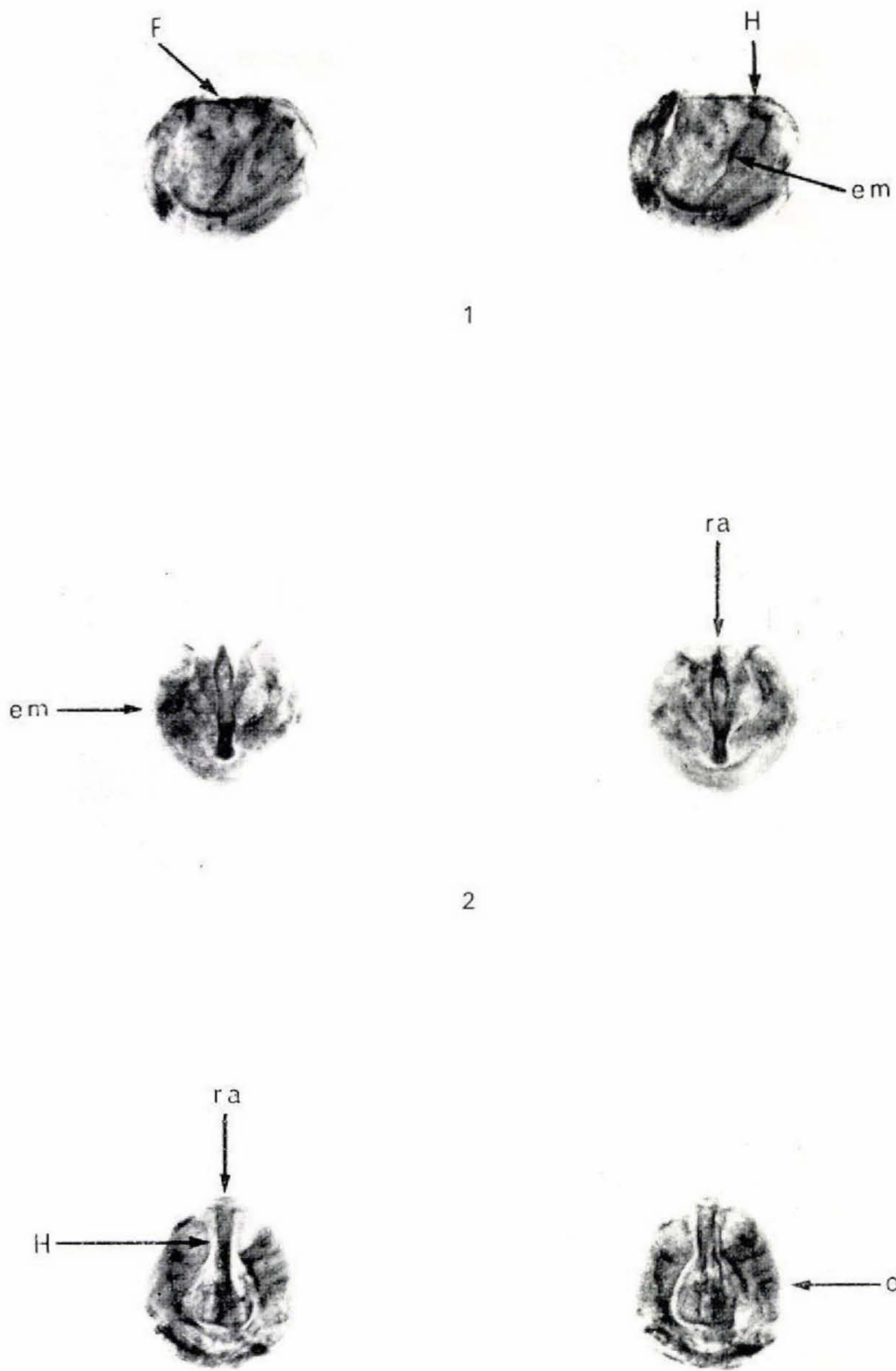